\title{
An overview of the host spectrum and distribution of Calodium hepaticum (syn. Capillaria hepatica): part 1-Muroidea
}

\author{
Hans-Peter Fuehrer
}

Received: 28 August 2013 / Accepted: 7 November 2013 /Published online: 19 November 2013

(C) The Author(s) 2013. This article is published with open access at Springerlink.com

\begin{abstract}
Calodium hepaticum (syn. Capillaria hepatica) is a worldwide-distributed species of zoonotic nematodes with a high affinity to the liver. Several rodent species of the superfamily Muroidea serve as main hosts for this pathogen. $C$. hepaticum has been found in Muroidean hosts in more than 60 countries in Europe; North, Central, and South America; Asia; Africa; and Oceania. C. hepaticum was documented in more than 90 Muroidean rodent species (Murinae, Deomyinae, Arvicolinae, Neotominae, Cricetinae, Sigmodontinae, Gerbillinae, and Cricetomyinae). Globally, the Norway rat (Rattus norvegicus) seems to be the main host species for this nematode. However, locally high prevalences (above $50 \%$ ) have also been observed in several other synanthropic (commensal and non-commensal) Muroidea species (e.g., Rattus tanezumi, Ondatra zibethicus, Apodemus sylvaticus). This review gives an overview of the distribution and host spectrum of $C$. hepaticum in Muroidea host species.
\end{abstract}

\section{Introduction}

Calodium hepaticum (syn. Capillaria hepatica) is a zoonotic nematode parasite distributed worldwide. Adults of this nematode parasitize the liver of mammals and lay their eggs into the liver parenchyma causing hepatic capillariasis. The eggs are only released into the environment with the death of the host. The main hosts of this parasite are rodents of the superfamily Muroidea (Schmidt 2001). Furthermore, this parasite has been documented in numerous other mammalian species including more than 70 human cases (reviewed in Fuehrer et al. 2011; Fuehrer 2013). Hepatic capillariasis is diagnosed

H.-P. Fuehrer $(\bowtie)$

Institute of Parasitology, Department of Pathobiology, University of Veterinary Medicine Vienna, Veterinärplatz 1, 1210 Vienna, Austria e-mail: hans-peter.fuehrer@vetmeduni.ac.at through necroscopy or biopsy only, because with hepatic infections eggs are not shed into the environment with the feces.

This review focuses on the Muroidea host spectrum and its geographic distribution in those hosts only. Information about the pathogenesis, ecology, and host spectrum in humans and other mammalians is given elsewhere (e.g., Fuehrer et al. 2011; Fuehrer 2013; Schmidt 2001).

For data evaluation, the systematic search was based on electronic databases (Scopus, PubMed, Google Scholar) and previous summaries (e.g., Schmidt 2001). The search terms Capillaria hepatica, Calodium hepaticum, Hepaticola hepatica, Trichocephalus hepaticus, and hepatic capillariasis were used. An attempt was made to include only those studies where the scientific names of the host and parasite were given clearly. Furthermore, spurious infections (= pseudoparasitism) were differentiated as far as possible from hepatic capillariasis. A short overview of spurious $C$. hepaticum infections in animals is given in Fuehrer (2013).

\section{Taxonomy}

C. hepaticum is a nematode out of the family Capillaridae (order Trichocephalida). Moravec (1982) categorized $C$. hepaticum in the genus Calodium. However, the name $C$. hepaticum is rarely used, and most researchers use the term Capillaria hepatica. Further synonyms are Trichocephalus hepaticus (Bancroft, 1893) and Hepaticola hepatica (Hall 1916) (Fuehrer et al. 2011).

The taxonomy of the family Capillaridae is disputed and pending. In the past, most species were included in the genus Capillaria. Recently, a molecular phylogenetic study revealed that Capillaridae can be clearly separated from Trichuridae (Guardone et al. 2013). However, the former genus Capillaria consists of a complex group of parasites including several 
parasites of carnivores and rodents of the genera Calodium, Eucoleus, Capillaria, Paracapillaria, Pearsonema, and Aonchotheca (Guardone et al. 2013). Three species are of zoonotic importance, namely Paracapillaria philippinensis (syn. Capillaria philippinensis), Eucoleus aerophila (syn. Capillaria aerophila), and C. hepaticum (syn. C. hepatica).

\section{Life cycle}

The life cycle of $C$. hepaticum is a direct one with a high affinity to the liver. After the ingestion of embryonated eggs, larvae hatch in the area of the caecum and invade the liver via the portal vein system. Adult worms parasitize in the liver of its mammalian hosts where the females lay eggs into the liver parenchyma after mating. The life span of adult worms is short (18-60 days post infection in mice) (Juncker-Voss et al. 2000; Schmidt 2001). The eggs develop in the host's liver to the eight-cell stage only. Unembryonated eggs are only released into the environment with the death of the host only (decay of host; excretion in feces of carnivores and omnivores or after cannibalism). Depending on the environmental conditions (e.g., humidity, temperature), eggs embryonate within 58 weeks. Laboratory studies revealed that embryonated eggs are viable for 25 months (reviewed in Juncker-Voss et al. 2000). The life cycle is closed when embryonated eggs are ingested from a mammalian host. The ingestion of nonembryonated eggs leads to pseudoparasitosis (= spurious infections) where the non-embryonated eggs are re-released with the feces and lead to mild symptoms only (reviewed in Fuehrer et al. 2011).

\section{Muroidea host spectrum}

The mammalian superfamily Muroidea consists of rodents with a worldwide distribution (with the exception of Antarctica) including animals like rats, true mice, gerbils, and hamsters. Recent molecular phylogenetic studies classified the superfamily into 6 families, 19 subfamilies, around 280 genera, and over 1,300 species (e.g., Steppan et al. 2004).

The host spectrum of C. hepaticum in Muroidea hosts (and in other mammals) indicates very low host specificity. More than 90 species of at least 44 genera of the superfamily Muroidea (Murinae, Arvicolinae, Neotominae, Cricetinae, Sigmodontinae, Gerbilinae, and Cricetomyinae) are known as hosts of this parasite (Table 1). Of these, more than 55 species are rodents of the subfamily Murinae including the Norway rat (Rattus norvegicus), Black rat (Rattus rattus), and house mouse (Mus musculus). Prevalences above $50 \%$ are regularly documented in Norway rats $(R$. norvegicus $)$ and Tanezumi rats (R. tanezumi), and rarely in house mice $(M$. musculus), long-tailed field mice (Apodemus sylvaticus), muskrats (Ondatra zibethicus), and bank voles (Myodes glareolus). All of these species are known as (commensal or non-commensal) synanthropic species. Human hepatic capillariosis cases are associated with poor hygienic conditions and the presence of rodents (e.g., rats) (Fuehrer et al. 2011). Davis (1951) reported that C. hepaticum is significantly less prevalent in decreasing rat populations than in stationary or increasing populations. A study conducted in Michigan (USA) with deer mice revealed that parasite prevalences are correlated negatively with heterozygosity when the effects of population density were held constant (Meagher 1998). Meagher further hypothesizes that inbred populations are more susceptible to parasite infestations. Differences in the prevalences of $C$. hepaticum in different rodent host species are thought to be associated with different living and nutritional habits (Schmidt et al. 1998). Several authors report that C. hepaticum occurs in localized foci of the examined study areas (e.g., Reperant and Deplazes 2005; Stojčević et al. 2002). Furthermore, cannibalism may be an important eggreleasing mechanism and is an important source of infection in burrows. On the other hand, predation seems to be responsible for scattered foci of infection (Farhang-Azad 1977a, b; Stojčević et al. 2002). Decomposition is thought to be a less important egg-releasing mechanism. Environmental conditions (humidity and temperature) are also associated with the distribution of these pathogens (e.g., Resendes et al. 2009). The pathogenicity of $C$. hepaticum in Muroidea hosts is considered low, although experimental infections of rats and mice have been demonstrated to lead to hepatic failure and the death of the host (the host survival rate is reduced by $5-10 \%$ ) (Singleton and Chambers 1996). However, individual variations of the host's inflammatory reaction to the parasite have been reported. Furthermore, hypersensitivity is associated with repeated infections (Borucinska and Nielsen 1993).

\section{Hepatic capillariasis—geographic distribution in Muroidea hosts}

C. hepaticum has been found in Muroidean hosts in more than 60 countries in Europe; North, Central, and South America; Asia; Africa; and Oceania. R. norvegicus is the rodent species with the highest prevalences worldwide. In Europe, North America, South America, and Asia, several studies reported prevalences above $50 \%$ in Norway rats (e.g., Easterbrook et al. 2007). Also other murid host species can present high prevalences in certain regions. In Asia, the nematode was found in prevalences above $50 \%$ in the common species $R$. tanezumi and the white bellied rat (Niviventer fuloscens) (e.g., Yuan et al. 2000; Zhou et al. 1998). Furthermore, the muskrat (O. zibethicus) seems to be an important host of $C$. hepaticum in North America (Borucinska and Nielsen 1993). In the UK, high prevalences of this parasite were observed in long-tailed 


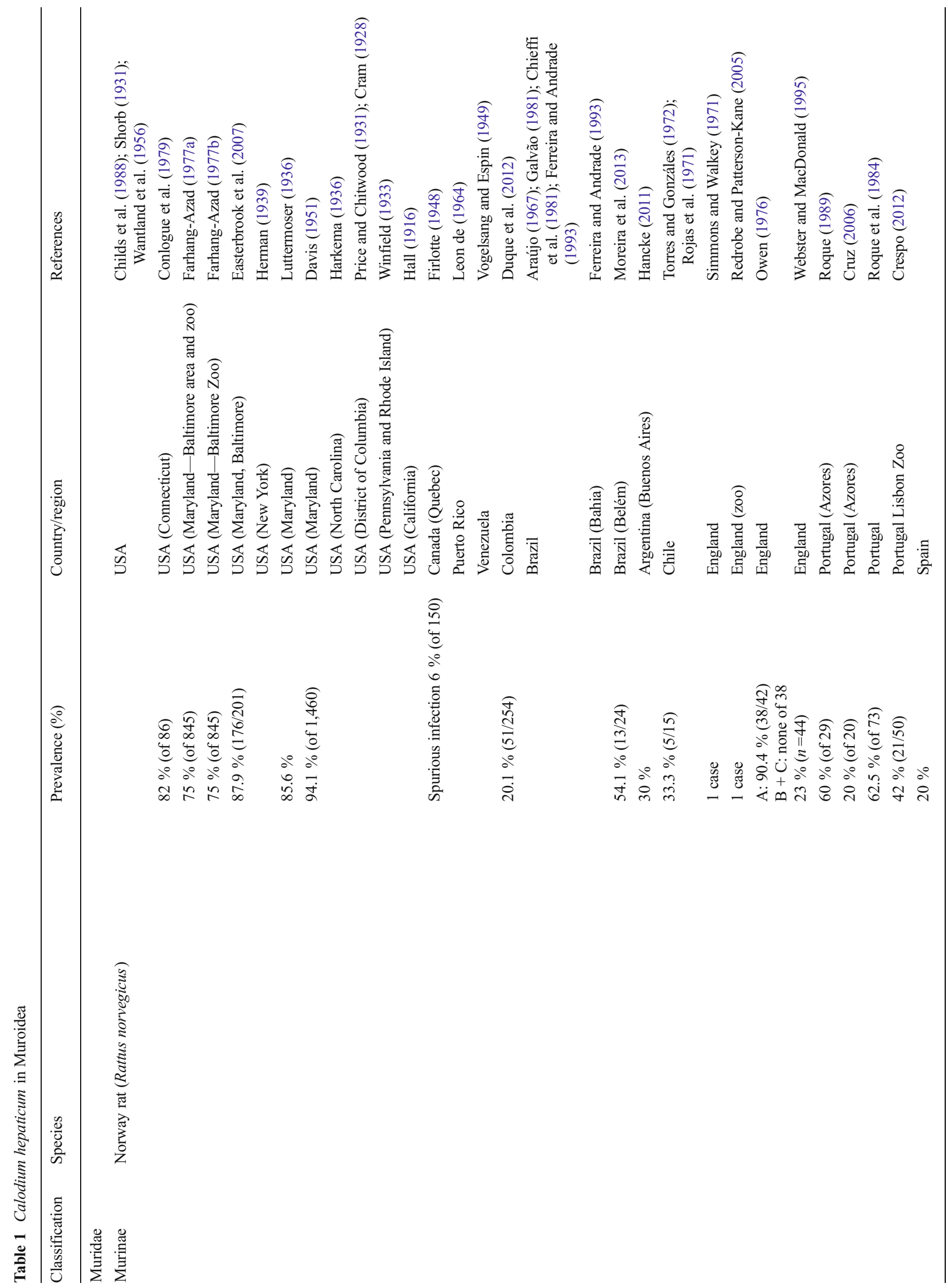




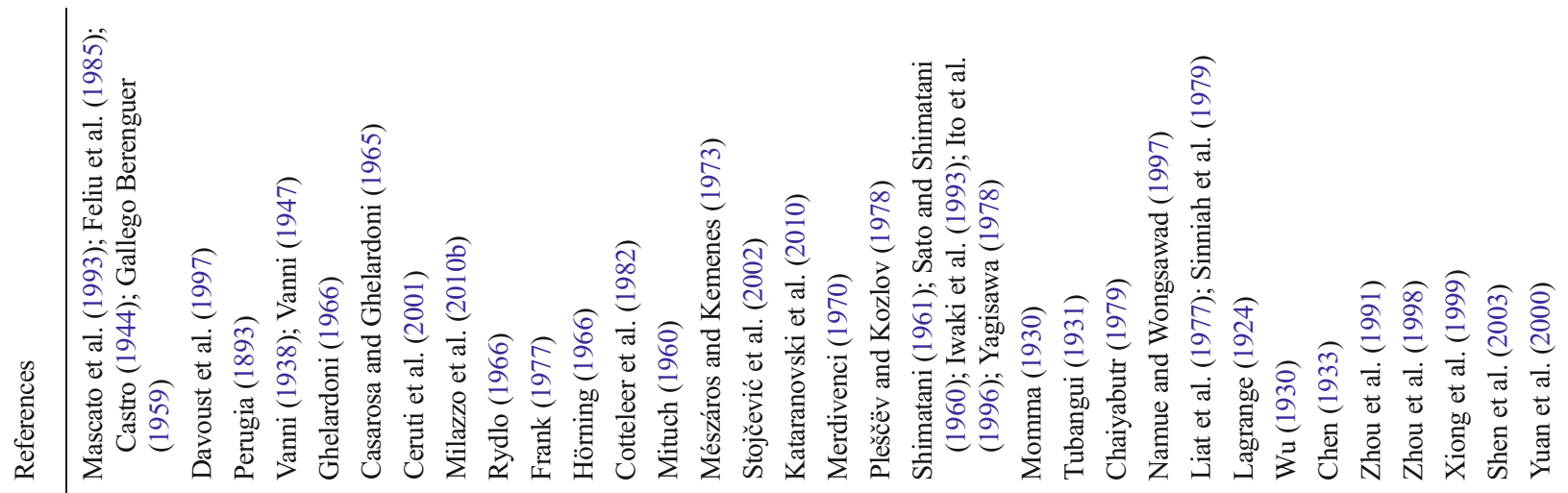

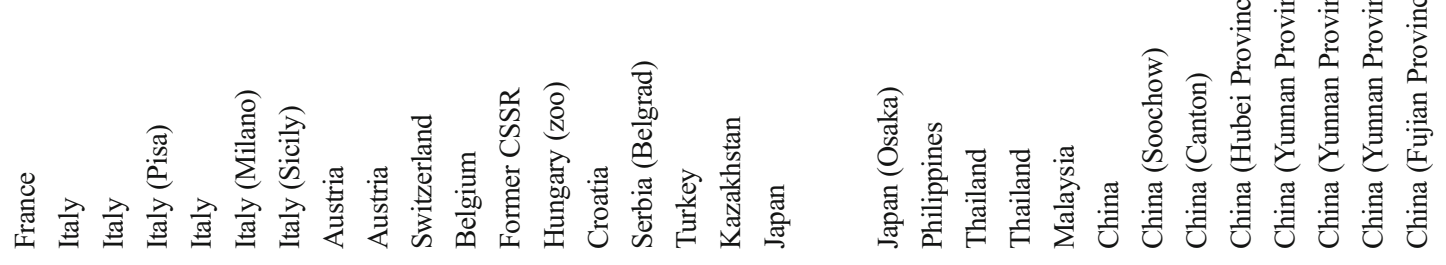

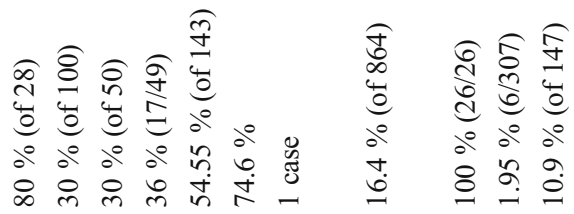

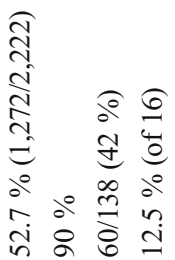

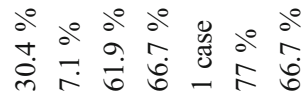




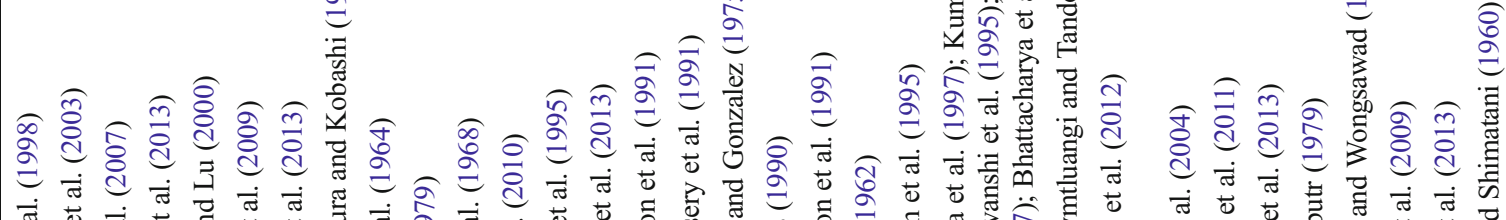

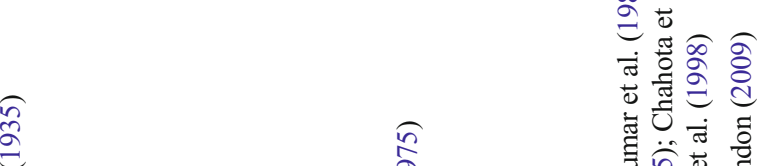

๘ิ

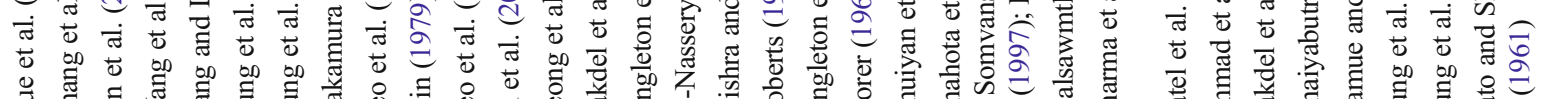

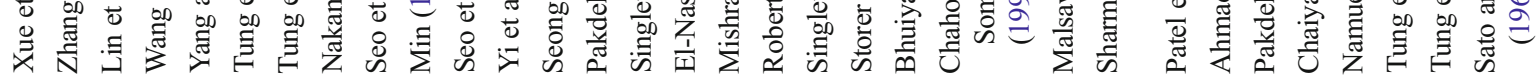

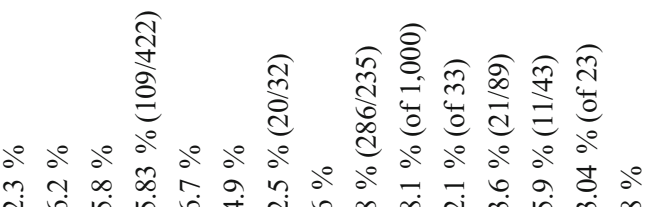

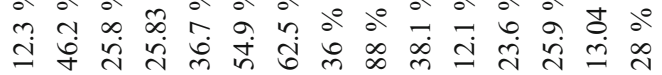

\begin{tabular}{rl} 
& \multicolumn{2}{c}{} \\
& 0 \\
$i$ & $i$ \\
in & $i$
\end{tabular}

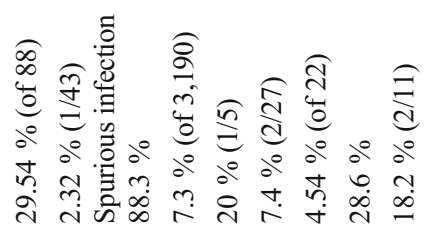



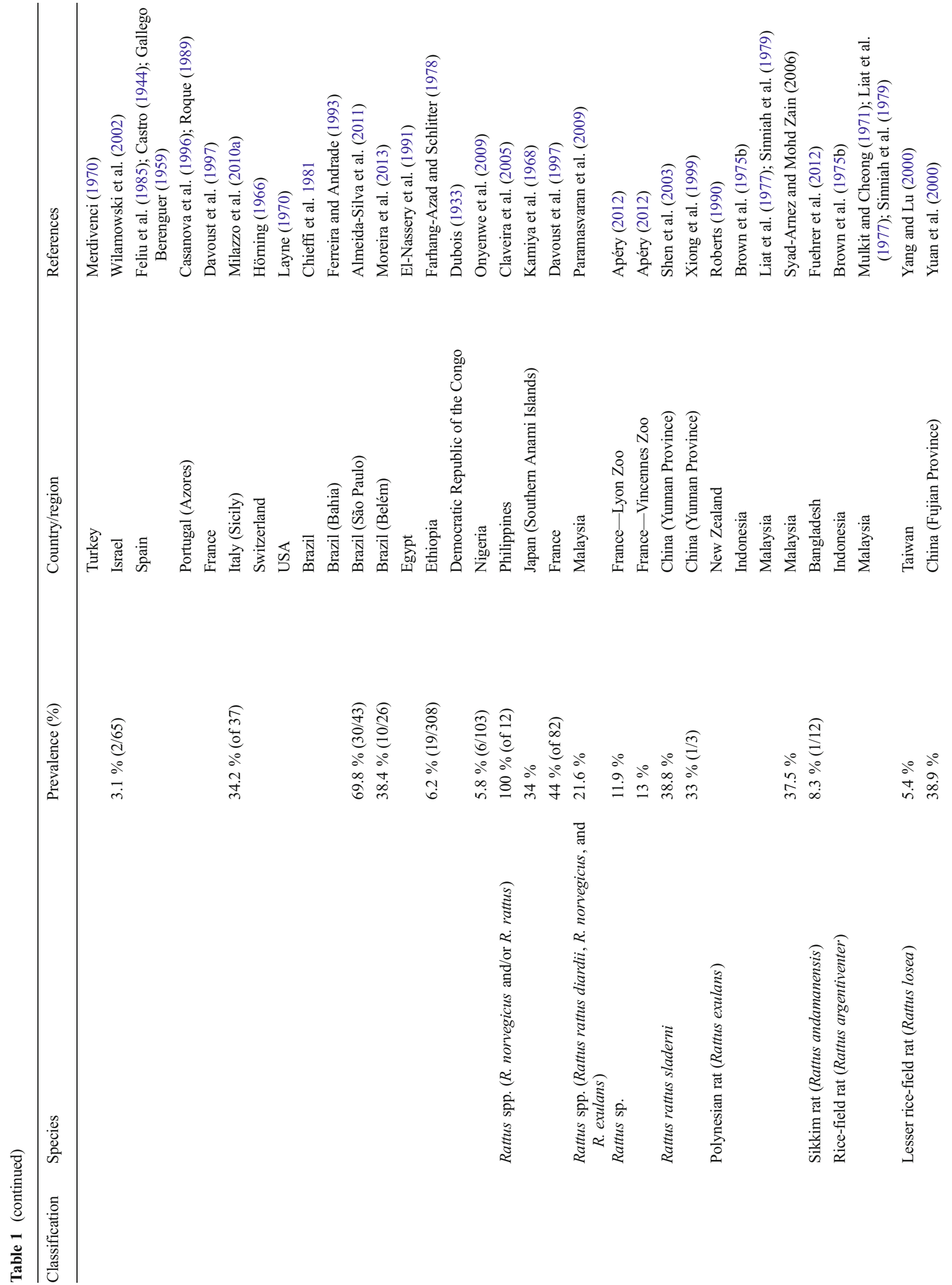


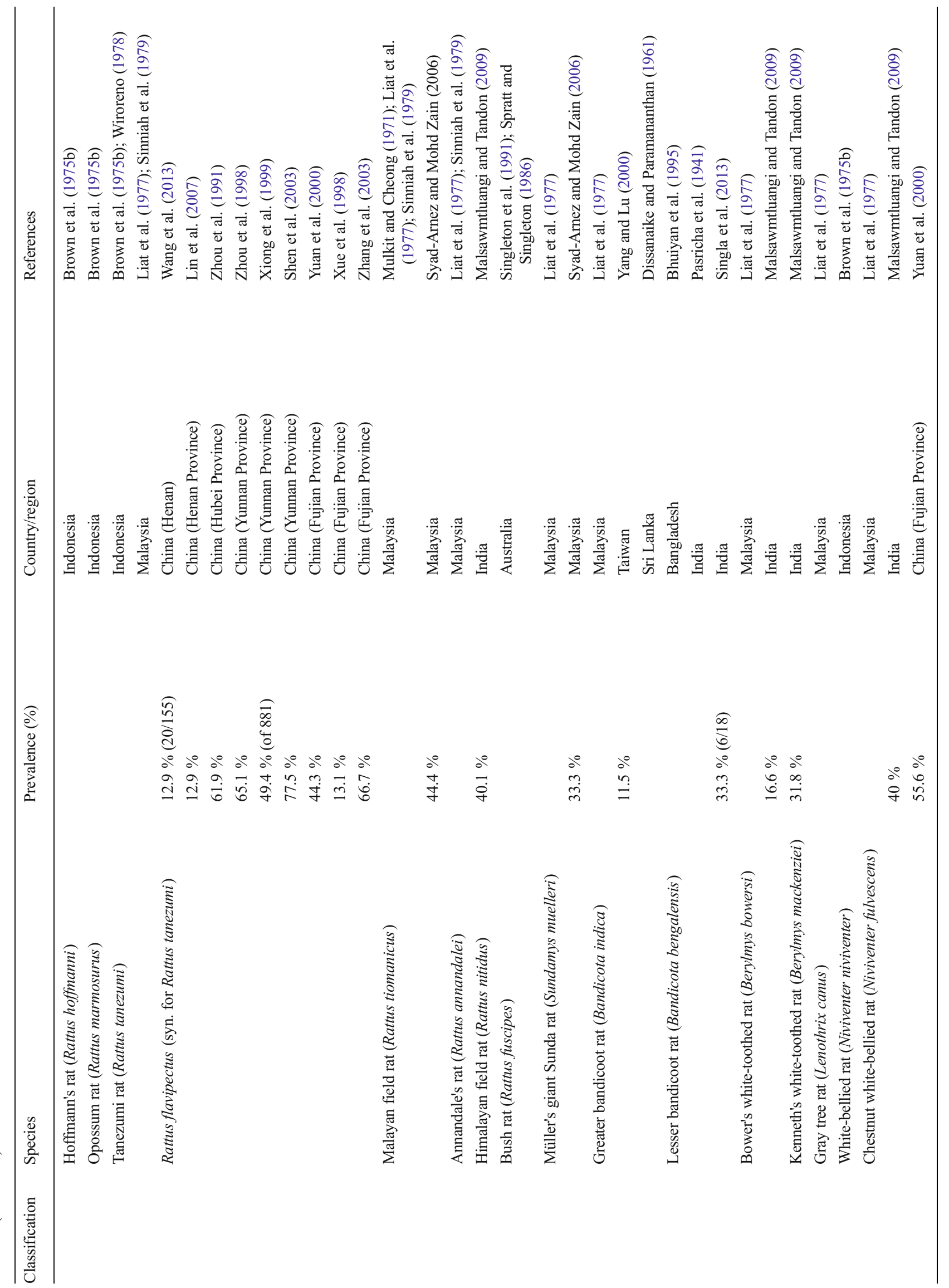




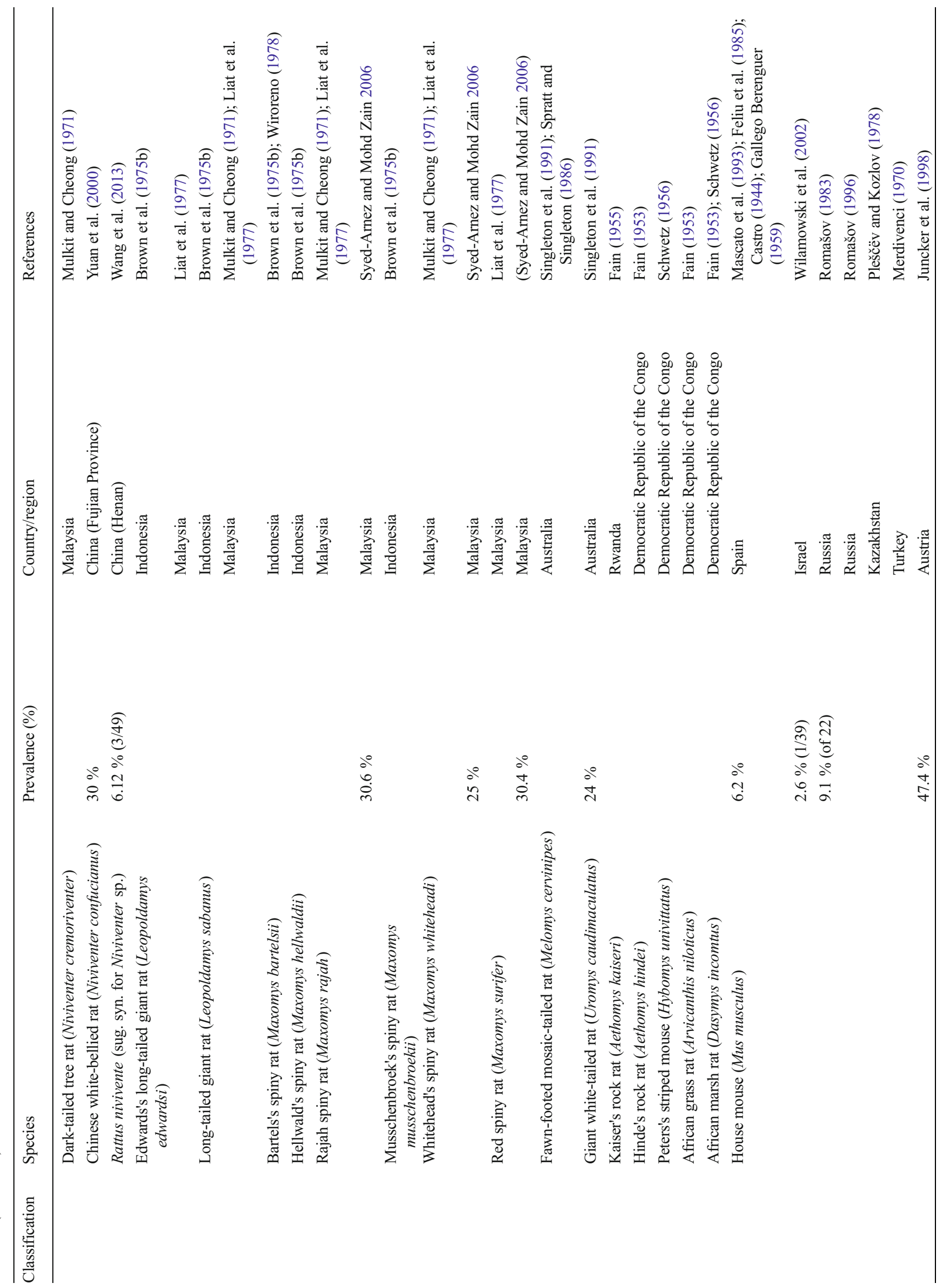




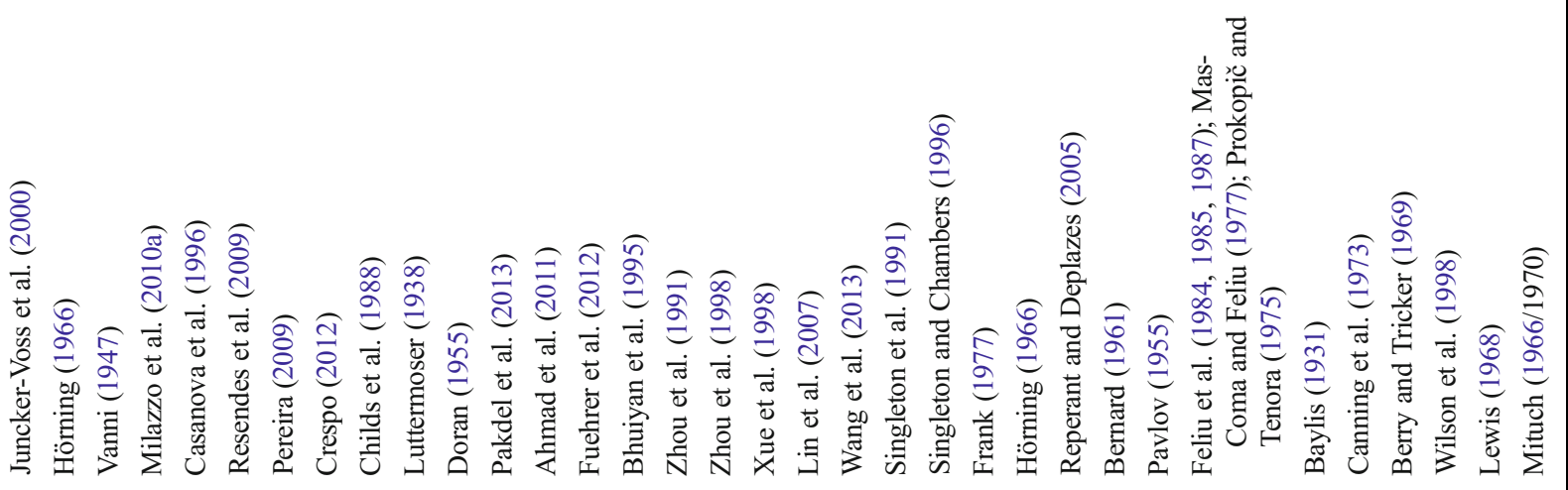

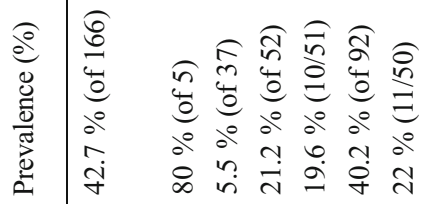

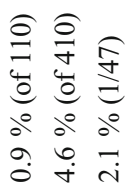

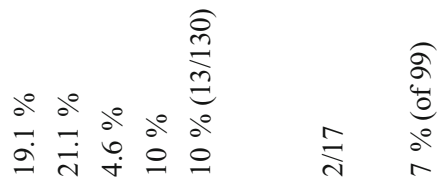

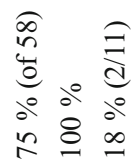

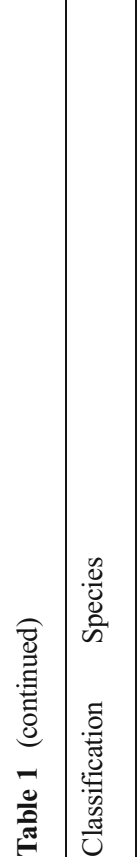

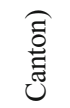




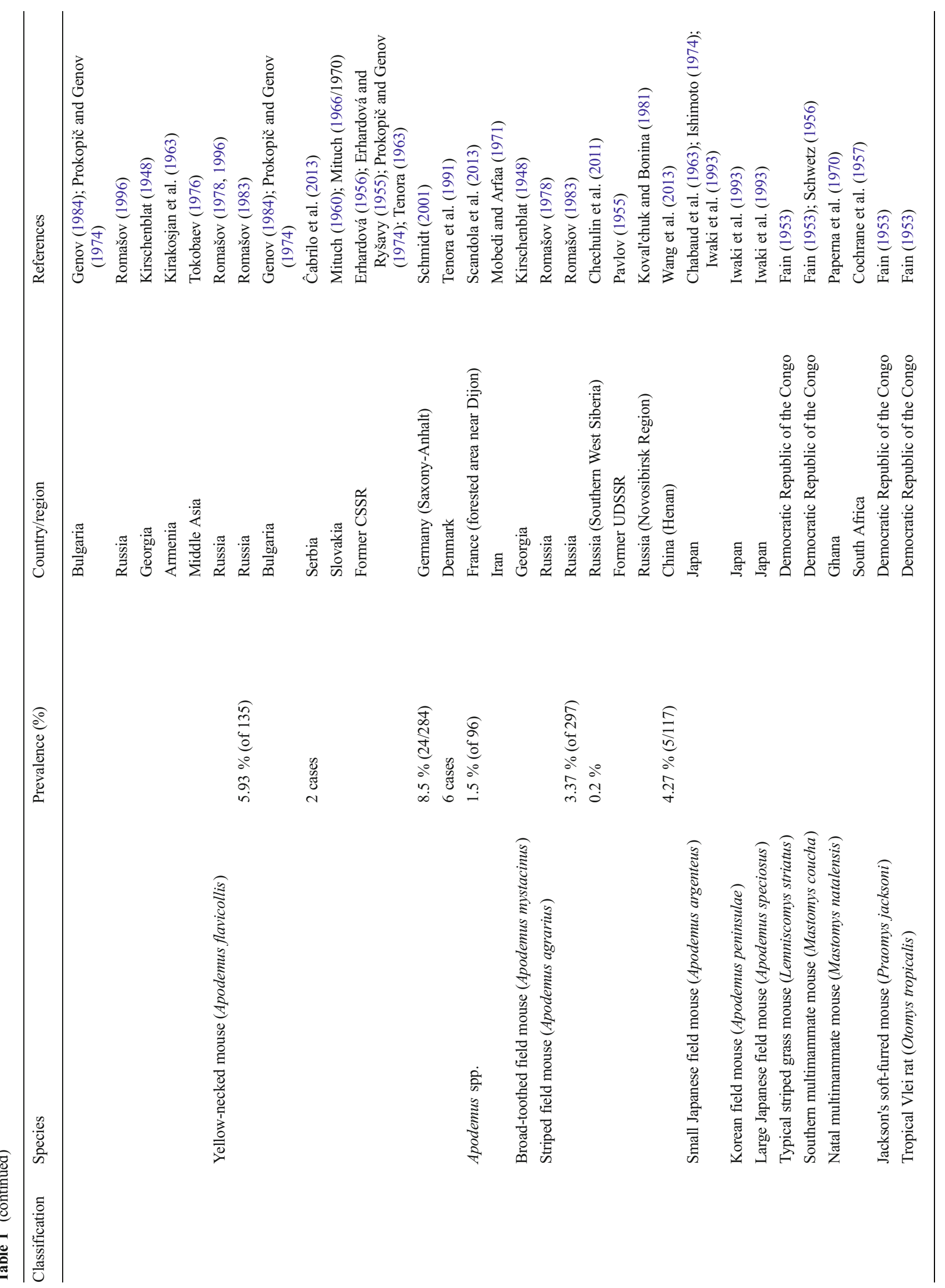




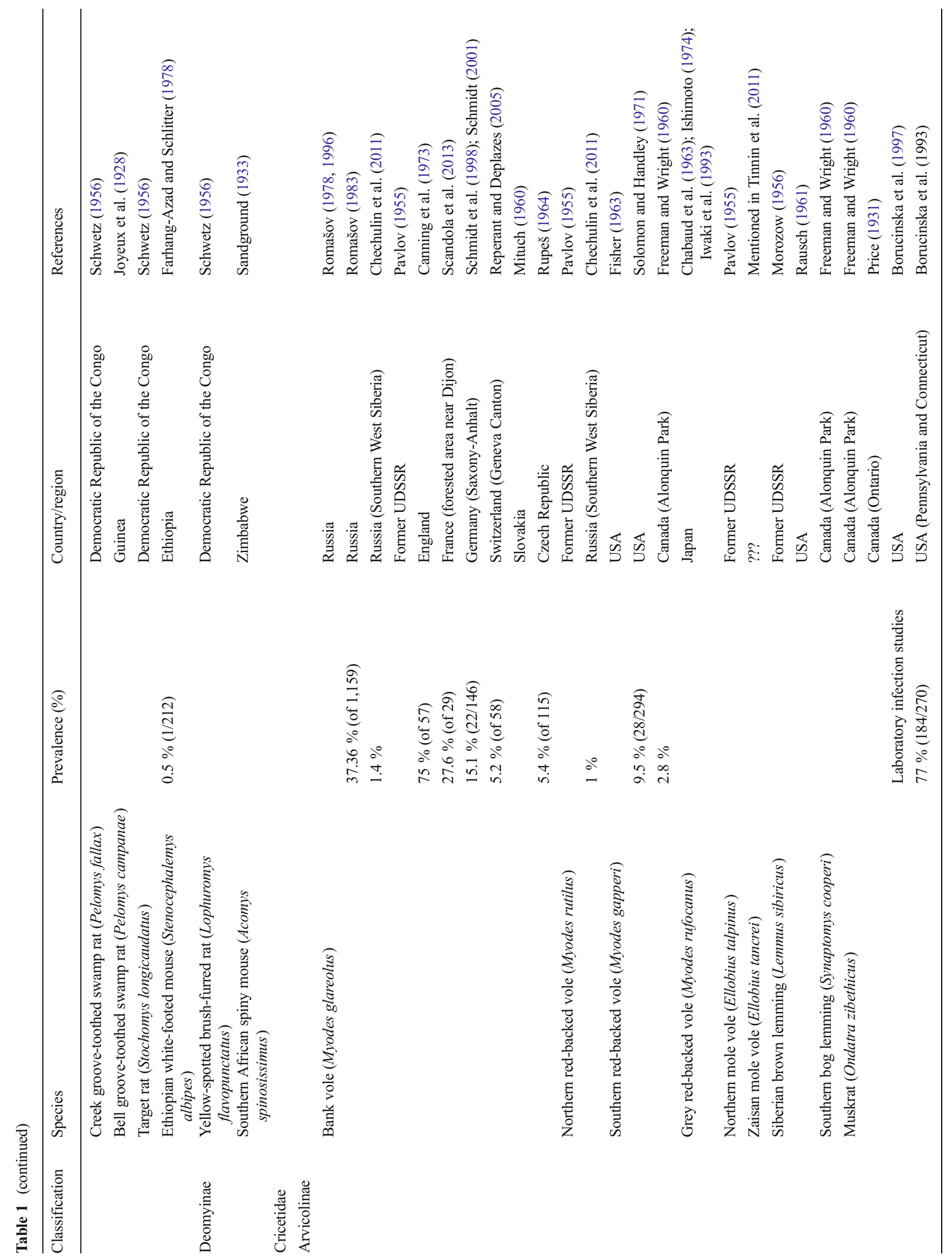




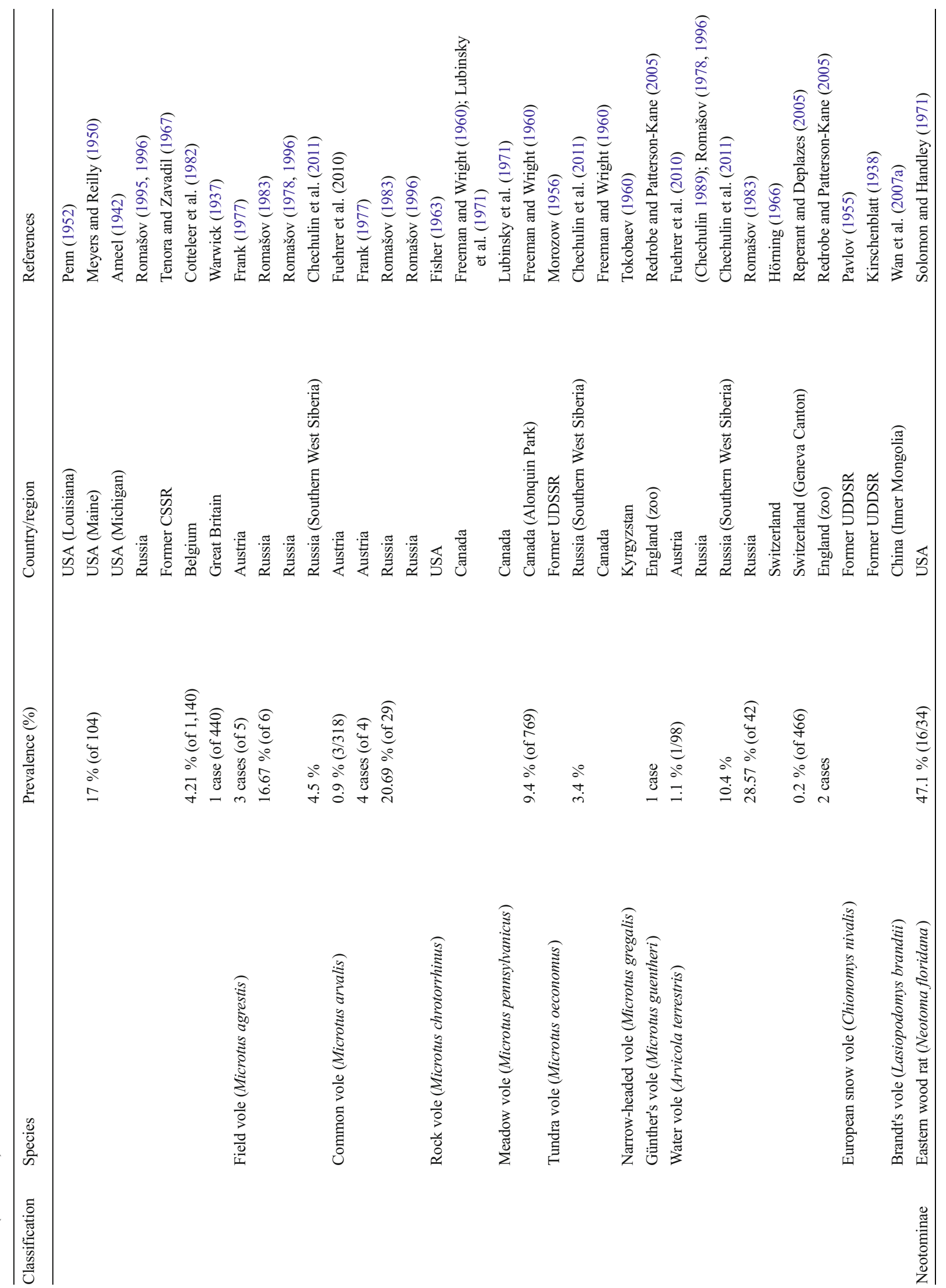




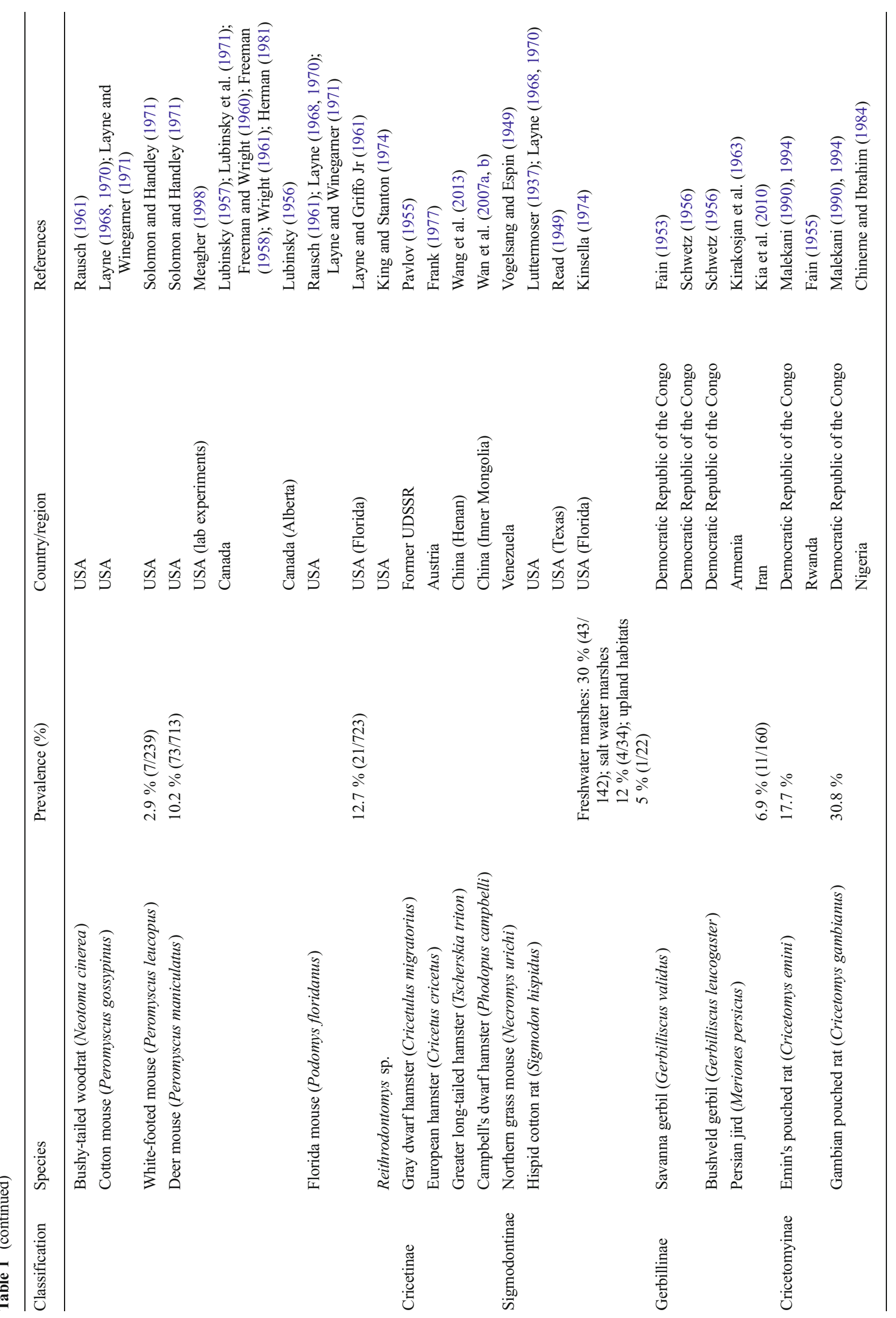


field mice (A. sylvaticus) and the bank vole (M. glareolus) (Canning et al. 1973).

\section{Conclusions}

C. hepaticum is a worldwide-distributed parasite with rodents of the superfamily Muroidea as main hosts. C. hepaticum has been described in more than 90 rodent species. Murinae and Arvicolinae are the hosts with the highest prevalences of this parasite. The Norway rat seems to be the most important host species with reported prevalences above $50 \%$ on several continents. However, a high percentage of the studies dealt with Norway rats only, and not with less common murid rodents. Especially synanthropic (commensal and noncommensal) Murinae and Arvicolinae seem to be the most affected hosts.

However, the diagnosis of this pathogen is limited to liver biopsies and necroscopy and so the true prevalence in Muroidea and other mammals remains unclear. At spurious infections, care should be taken to exclude mix-ups with other Trichuridae and Capillaridae shedding eggs of almost similar morphology (e.g., Bork-Mimm and Rinder 2011; Di Cesare et al. 2011; Stuart et al. 2013; Traversa et al. 2011). Novel (molecular) diagnostic tools for proper (molecular) species classification are of urgent need.

Acknowledgments I wish to thank all authors who provided personal copies of their manuscripts.

Conflict of interest The author declares that he has no conflict of interest.

Open Access This article is distributed under the terms of the Creative Commons Attribution License which permits any use, distribution, and reproduction in any medium, provided the original author(s) and the source are credited.

\section{References}

Ahmad MS, Maqbool A, Mahmood-ul-Hassan M, Mushtaq-ul-Hassan M, Anjum AA (2011) Capillaria hepatica (Nematode) in rodents of the Lahore Metropolis Corporation-Pakistan. J Anim Plant Sci 21(4):787-793

de Almeida-Silva MJF, del Fava C, Potenza M, Reis F, de Carvalho Campos AE (2011) Diagnosis of Capillaria hepatica in Rattus rattus by histopathology. Proceedings of the Seventh International Conference on Urban Pests. Instutio Biologico, São Paulo, SP, Brazil

Ameel D (1942) Two larval cestodes from the muskrat. Trans. Amer. Microsc. Soc. 69: 267-271. In: Lubinsky G (1956) On the probable presence of parasitic liver cirrhoses in Canada. Can J Comp Med Vet Sci. 20, 457-465

Apéry S (2012) La capillariose hépatique dans quatre parcs zoologiques en France. Thése. Doctorat Vétérinaire. La Faculté de Médecine de Créteil. École Nationale Vétérinaire D’Alfort. pp. 104
Araújo P (1967) Helmintos de Rattus norvegicus (Berkenhout, 1769) da cidade de São Paulo. Rev. Fac. Farm. Bioquím. Universade de São Paulo (5)1:141-159.

Baylis HA (1931) On the structure and relationships of the nematode Capillaria (Hepaticola) hepatica (BANCROFT). Parasitology 23, 533-543. In: Schmidt S (2001) Untersuchungen zum Vorkommen von Capillaria hepatica und Metazestoden der Cyclophyllida bei Wildmäusen in Deutschland. PhD Thesis, Universität., Veterinärmedizinische Fakultät, Leipzig:145pp.

Bernard J (1961) Liste de nematodes parasites des micromammiferes de la fauna Belge. Ann. Parasitol. Hum. Comp. 36: 775-784. In: Asakawa M, Tenora F (1996) A checklist of nematode parasites of the genus Apodemus (Murinae: Rodentia) throughout the world excluding Japan. J. Rakuno Gakuen Univ 20 (2): 181-213

Berry RJ, Tricker BJK (1969) Competition and extinction. The mice of Foula, with notes on those of Fair Isle and St Kilda. J Zool. 158: 247-265. In: Lloyd S, Elwood CM, Smith KC (2002) Capillaria hepatica (Calodium hepaticum) infection in a British dog. Vet Rec. 151(14):419-20

Bhattacharya D, Sikdar A, Sarma U, Ghosh AK, Biswas G (1998) Concurrent infection of Capillaria hepatica and Cysticercus fasciolaris in rat (Rattus rattus) - a preliminary note. Indian Vet $\mathbf{J}$ 75(5):486

Bhuiyan AI, Ahmed TA, Khanum H (1995) Endoparasitic helminths of rats and mice from Tangail area. Bangladesh $\mathrm{J}$ Sci Res 13(1):75-80

Borucinska JD, van Kruiningen HJ, Caira JN, Garmendia AE (1997) Clinicopathological features and histopathology of experimental hepatic capillariasis in muskrats (Ondatra zibethicus). J Wildl Dis 29(3):518-20

Bork-Mimm S, Rinder H (2011) High prevalence of Capillaria plica infections in red foxes (Vulpes vulpes) in Southern Germany. Parasitol Res 108(4):1063-7. doi:10.1007/s00436010-2196-0

Borucinska JD, Nielsen SW (1993) Hepatic capillariasis in muskrats (Ondatra zibethicus). J Wildl Dis 29:518-520

Brown RJ, Carney WP, van Peenen PFD, Cross JH, Saroso JS (1975) Capillariasis in wild rats of Indonesia. Southeast Asian J Trop Med Pub Hlth 6:219-222

Ĉabrilo B, Jovanović V, Budinski Ivana, Blagojević Jelena, Vujošević M, Bjelić-Ĉabrilo O (2013) First report of Capillaria hepatica (Bancroft, 1893) in Apodemus flavicollis in Serbia. Third International Epizootiology Days and Serbian Epizootiology Days 2013. Abstract. 178

Canning EU, Cox FEG, Croll NA, Lyons KM (1973) The natural history of Slapton Ley Nature Reserve: VI studies on the parasites. Field Studies 3, 681-718. In: Schmidt S (2001) Untersuchungen zum Vorkommen von Capillaria hepatica und Metazestoden der Cyclophyllida bei Wildmäusen in Deutschland. PhD Thesis, Universität., Veterinärmedizinische Fakultät, Leipzig:145pp.

Casanova JC, Miquel J, Fons R, Molina X, Feliu C, Mathias ML, Torres J, Libois R, Santos-Reis M, Collares-Pereira M, Marchand B (1996) On the helminthofauna of wild mammals (Rodentia, Insectivora and Lagomorpha) in Azores Archipelago (Portugal). Vie et Milieu 46(3/ 4): 253-259. In: Crespo APMAM (2012) Controlo de pragas no jardim zoológico de Lisboa particular relevância para o controlo de roedores e sua infeção parasitária. Dissertação de Mestrad em Segurança Alimentar. Faculdade de Medicina Veterinária. Universidade Técnica de Lisboa. pp. 174

Casarosa L, Ghelardoni E (1965) Prime ricerche sulla diffusione della Capillaria hepatica (BANCROFT 1893) nei ratti delle chiaviche (Rattus norvegicus) della provincia di Pisa. Annali della Facolta di Medicina Veterinaria di Torino 15, 203-205. In: Schmidt S (2001) Untersuchungen zum Vorkommen von Capillaria hepatica und Metazestoden der Cyclophyllida bei Wildmäusen in Deutschland. 
PhD Thesis, Universität., Veterinärmedizinische Fakultät, Leipzig: $145 \mathrm{pp}$.

Castro JG (1944) Contribucion al estudio del parasitismo por helmintos o sus fases larvarias de diversos muridos capturados en Granada. Revista iberica de parasitologia 4, 38-60. In: Schmidt S (2001) Untersuchungen zum Vorkommen von Capillaria hepatica und Metazestoden der Cyclophyllida bei Wildmäusen in Deutschland. $\mathrm{PhD}$ Thesis, Universität., Veterinärmedizinische Fakultät, Leipzig: $145 \mathrm{pp}$.

Ceruti R, Sonzogni O, Origgi F, Vezzoli F, Cammarata S, Giusti AM, Scanziani E (2001) Capillaria hepatica infection in wild brown rats (Rattus norvegicus) from the urban area of Milan, Italy. J Vet Med B Infect Dis Vet Public Health 48(3):235-40

Chabaud AG, Rausch RL, Desset MC (1963) Nématodes parasites de rongeurs et insectivores Japonais. B Soc Zool Fr. 88, 489-512. In: Schmidt S (2001) Untersuchungen zum Vorkommen von Capillaria hepatica und Metazestoden der Cyclophyllida bei Wildmäusen in Deutschland. PhD Thesis, Universität., Veterinärmedizinische Fakultät, Leipzig:145pp.

Chahota R, Asrani RK, Katoch RC, Jithendran KP (1997) Hepatic capillariasis in a wild rat (Rattus rattus). Journal of Veterinary Parasitology 11(1):87-90

Chaiyabutr N (1979) Hepatic capillariasis in Rattus norvegicus . J Sci Soc Thailand 5:48-50

Chechulin AI (1989) Structure of the helminth fauna of the water rat during the period of its mass multiplication in northern Baraba. In: Schmidt S (2001) Untersuchungen zum Vorkommen von Capillaria hepatica und Metazestoden der Cyclophyllida bei Wildmäusen in Deutschland. PhD Thesis, Universität., Veterinärmedizinische Fakultät, Leipzig:145pp.

Chechulin AI, Kapenko SV, Panov VV (2011) Ecology of Hepaticola hepatica infection in rodents in Southern West Siberia. Contemporary Problems of Ecology 4(4):423-427

Chen HT (1933) A preliminary report on a survey of animal parasites of Canton, China, rats. Lingnan Sc. Jour. 12(1): 65-74. In: Seo BS, Rim HJ, Lee CW, Yoon JS (1964) Studies on the parasitic helminths of Korea: II. Parasites of the rat, Rattus norvegicus Erxl. In Seoul, with the description of Capillaria hepatica (Bancroft, 1893) Travassos, (1915). Kisaengchunghak Chapchi. 2(1):55-62

Chieffi PP, Dias RMDS, Mangini ACS, Grispino DMA, Pacheco MAD (1981) Capillaria hepatica (Bancroft, 1893) em murídeos capturados no município de São Paulo SP. Brasil Rev Inst Med Trop São Paulo 23(4):143-146

Childs JE, Glass GE, Korch GW (1988) The comparative epizootiology of Capillaria hepatica (Nematoda) in urban rodents from different habitats of Baltimore, Maryland. Can J Zool 66: 2769-2775. In: Schmidt S (2001) Untersuchungen zum Vorkommen von Capillaria hepatica und Metazestoden der Cyclophyllida bei Wildmäusen in Deutschland. PhD Thesis, Universität., Veterinärmedizinische Fakultät, Leipzig:145pp.

Chineme CN, Ibrahim MA (1984) Hepatica capillariasis in African giant rats (Cricetomys gambianus WATERHOUSE). J Wildl Dis 20:341342

Claveria FG, Causapin J, de Guzman MA, Toledo MG, Salibay C (2005) Parasite biodiversity in Rattus spp caught in wet markets. Southeast Asian J Trop Med Public Health 36(Suppl 4):146-8

Cochrane JC, Sagorin L, Wilcocks MG (1957) Capillaria hepatica infection in man; a syndrome of extreme eosinophilia, hepatomegaly and hyperglobulinaemia. S Afr Med J 31(30):751-755

Conlogue G, Foreyt W, Adess M, Levine H (1979) Capillaria hepatica (Bancroft) in select rat populations of Hartford, Connecticut, with possible public health implications. J Parasitol 65(1):105-8

Cotteleer C, Famerée L, van den Abbeele O (1982) Les Parasites de l'appareil digestif du surmulot (Rattus norvegicus) et du rat musqué (Ondatra zibethica) en Belgique. Incidence sanitaire pour l'homme et les animaux domestiques. Schweiz Arch Tierh. 124: 447-455. In:
Schmidt S (2001) Untersuchungen zum Vorkommen von Capillaria hepatica und Metazestoden der Cyclophyllida bei Wildmäusen in Deutschland. PhD Thesis, Universität., Veterinärmedizinische Fakultät, Leipzig:145pp.

Cram EB (1928) A note on parasites of rats (Rattus norvegicus and Rattus norvegicus albus). J. Parasit. 15: 72. In: Lubinsky G (1956) On the probable presence of parasitic liver cirrhoses in Canada. Can J Comp Med Vet Sci. 20: 457-465

Crespo APMAM (2012) Controlo de pragas no jardim zoológico de Lisboa particular relevância para o controlo de roedores e sua infeção parasitária. Dissertação de Mestrad em Segurança Alimentar. Faculdade de Medicina Veterinária. Universidade Técnica de Lisboa. pp. 174

Cruz JSP (2006) Fatores de variação da fauna helmintológica em populações de roedores da ilha de São Miguel (Açores). Atas del X Congreso Ibérico de Parasitologia (CIP 10), P 71, Madrid: Servicio de Publicaciones, Universidad Complutense de Madrid. ISBN 978-84-96704-04-6. In: Crespo APMAM (2012) Controlo de pragas no jardim zoológico de Lisboa particular relevância para o controlo de roedores e sua infeção parasitária. Dissertação de Mestrad em Segurança Alimentar. Faculdade de Medicina Veterinária. Universidade Técnica de Lisboa. pp. 174

Davis DE (1951) The relation between the level of population and the prevalence of Leptospira, Salmonella and Capillaria in Norway rats. Ecology 32(3):465-468

Davoust B, Boni M, Branquet D, Ducos de Lahitte J, Martet G (1997) Recherche de trois infestations parasitaires chez des rats capturés à Marseille: évaluation du risque zoonosique. B Acad Nat Med Paris 181: 887-897. In: Schmidt S (2001) Untersuchungen zum Vorkommen von Capillaria hepatica und Metazestoden der Cyclophyllida bei Wildmäusen in Deutschland. PhD Thesis, Universität., Veterinärmedizinische Fakultät, Leipzig:145pp.

Di Cesare A, Castagna G, Meloni S, Milillo P, Latrofa S, Otranto D, Traversa D (2011) Canine and feline infections by cardiopulmonary nematodes in central and southern Italy. Parasitol Res 109(Suppl 1): S87-96. doi:10.1007/s00436-011-2405-5

Dissanaike AS, Paramananthan DC (1961) On Capillaria hepatica infection in the Ceylon bandicoot (Bandicota malabarica). The Ceylon Veterinary journal 9: 9-11. In: Schmidt S (2001) Untersuchungen zum Vorkommen von Capillaria hepatica und Metazestoden der Cyclophyllida bei Wildmäusen in Deutschland. $\mathrm{PhD}$ Thesis, Universität., Veterinärmedizinische Fakultät, Leipzig: $145 \mathrm{pp}$.

Doran D (1955) A catalogue of the protozoa and helminths of North American rodents. III. Nematoda. Amer. Midland Nat. 53 : 162-175. In: Lubinsky G (1956) On the probable presence of parasitic liver cirrhoses in Canada. Can J Comp Med Vet Sci. 20: $457-465$

Dubois A (1933) Sur l'existence de Hepaticola hepatica au Congo belge. Ann Soc Belg Med Tr. 13, 259-260. In: Schmidt S (2001) Untersuchungen zum Vorkommen von Capillaria hepatica und Metazestoden der Cyclophyllida bei Wildmäusen in Deutschland. PhD Thesis, Universität., Veterinärmedizinische Fakultät, Leipzig: $145 \mathrm{pp}$.

Duque BA, Aranzazu D, Agudelo-Flórez P, Londoño AF, Quiroz VH, Rodas JD (2012) Rattus norvegicus as an indicator of circulation of Capillaria hepatica and Taenia taeniaeformis on a groceries trade center of Medellín, Colombia. Biomedica. 32(4):510-8. doi: 10.1590/S0120-41572012000400006. Spanish.

Easterbrook JD, Kaplan JB, Vanasco NB, Reeves WK, Purcell RH, Kosoy MY, Glass GE, Watson J, Klein SL (2007) A survey of zoonotic pathogens carried by Norway rats in Baltimore, Maryland, USA. Epidemiol Infect 135(7):1192-9

El-Nassery SF, El-Gebali WM, Oweiss NY (1991) Capillaria hepatica: an experimental study of infection in white mice. J Egypt Soc Parasitol 21:467-478 
Erhardová B (1956) Parasitičti červi nasich mysovitych hlodavcu II. Českolov. Parasitol. 3: 49-66. In: Asakawa M, Tenora F (1996) A checklist of nematode parasites of the genus Apodemus (Murinae: Rodentia) throughout the world excluding Japan. J. Rakuno Gakuen Univ 20 (2): 181-213

Erhardová B, Ryšavy B (1955) Př́íspěvek k poznání cizopasných červů našich myší a hrabošů. Zoologicke a entomologicke listy 4: 71-90. In: Schmidt S (2001) Untersuchungen zum Vorkommen von Capillaria hepatica und Metazestoden der Cyclophyllida bei Wildmäusen in Deutschland. PhD Thesis, Universität., Veterinärmedizinische Fakultät, Leipzig:145pp.

Fain A (1953) Observations sur Hepaticola hepatica (BANCROFT, 1893) Hall 1916 au Congo, Belge. Ann Soc Belg Med Tr 33:107117

Fain A (1955) Deux nouveaux hôtes pour Hepaticola hepatica (BANCROFT) au Ruanda-Urundi. Rev Zool Bot Afr 51:11-12

Farhang-Azad A (1977a) Ecology of Capillaria hepatica (Bancroft 1893) (Nematoda). I. Dynamics of infection among Norway rat populations of the Baltimore Zoo, Baltimore, Maryland. J Parasitol 63:117-122

Farhang-Azad A (1977b) Ecology of Capillaria hepatica (BANCROFT 1893) (Nematoda). II. Egg-Releasing mechanisms and transmission. J Parasitol 63:701-706

Farhang-Azad A, Schlitter DA (1978) Capillaria hepatica in small mammals collected from Shoa Province, Ethiopia. J Wildl Dis 14: 358-361

Feliu C, Mas-Coma S, Gallego J (1984) Contribution al conociemiento de la Helmintofauna de micromamiferos ibericos. VIII. Nuevos datos sobre parasitos de Apodemus sylvaticus LINNAEUS, 1758 (Rodentia: Muridae). Revista Iberica de Parasitologia 44, 109-128. In: Schmidt S (2001) Untersuchungen zum Vorkommen von Capillaria hepatica und Metazestoden der Cyclophyllida bei Wildmäusen in Deutschland. PhD Thesis, Universität., Veterinärmedizinische Fakultät, Leipzig:145pp.

Feliu C, Mas-Coma S, Gallego J (1985) Coneixements actuals sobre l'helmintofauna paràsita dels múrids (Rodentia) a Catalunya. Butlleti de la Institucio Catalana d'Historia Natural, Filial de l'Institut d'Estudis Catalans 50: 255-261. In: Schmidt S (2001) Untersuchungen zum Vorkommen von Capillaria hepatica und Metazestoden der Cyclophyllida bei Wildmäusen in Deutschland. $\mathrm{PhD}$ Thesis, Universität., Veterinärmedizinische Fakultät, Leipzig: $145 \mathrm{pp}$.

Feliu C. Gracenea M, Torregrosa M (1987) Ecological evaluation of the helminth parasites of Apodemus sylvaticus (Rodentia: Muridae) in the Spanish Eastern Pyrenees. In: Asakawa M, Tenora F (1996) A checklist of nematode parasites of the genus Apodemus (Murinae: Rodentia) throughout the world excluding Japan. J. Rakuno Gakuen Univ 20(2): 181-213

Ferreira LA, Andrade ZA (1993) Capillaria hepatica: a cause of septal fibrosis of the liver. Mem I Oswaldo Cruz 88:441-447

Firlotte WA (1948) A survey of the parasites of the brown Norway rat. Cand J Comp Med 12:187-191

Fisher RL (1963) Capillaria hepatica from the rock vole in New York. Journal of parasitology 49, 450. In: Schmidt S (2001) Untersuchungen zum Vorkommen von Capillaria hepatica und Metazestoden der Cyclophyllida bei Wildmäusen in Deutschland. $\mathrm{PhD}$ Thesis, Universität., Veterinärmedizinische Fakultät, Leipzig: $145 \mathrm{pp}$.

Frank C (1977) Kleinsäugerhelminthen im Neusiedlerseegebiet. Angewandte Parasitologie 18:206-216

Freeman RS (1958) On the epizootiology of Capillaria hepatica (BANCROFT, 1893) in Algonquin Park, Ontario. J Parasitol 44: 33. In: Schmidt S (2001) Untersuchungen zum Vorkommen von Capillaria hepatica und Metazestoden der Cyclophyllida bei Wildmäusen in Deutschland. PhD Thesis, Universität., Veterinärmedizinische Fakultät, Leipzig:145pp.
Freeman RS, Wright KA (1960) Factors concerned with the epizootiology of Capillaria hepatica (BANCROFT, 1893) (Nematoda) in a population of Peromyscus maniculatus in Algonquin Park, Canada. J Parasitol 46:373-382

Führer HP, Schneider R, Walochnik J, Auer H (2010) Extraintestinal helminths of the common vole (Microtus arvalis) and the water vole (Arvicola terrestris) in Western Austria (Vorarlberg). Parasitol Res 106(4):1001-4. doi:10.1007/s00436-010-1753-x

Fuehrer HP, Igel P, Auer H (2011) Capillaria hepatica in man-an overview of hepatic capillariosis and spurious infections. Parasitol Res 109(4):969-79. doi:10.1007/s00436-011-2494-1

Fuehrer HP, Baumann TA, Riedl J, Treiber M, Igel P, Swoboda P, Joachim A, Noedl H (2012) Endoparasites of rodents from the Chittagong Hill Tracts in Southeastern Bangladesh. Wien Klin Wochenschr 124(Suppl 3):27-30. doi:10.1007/s00508-012-0237-7

Fuehrer HP (2013) An overview on the host spectrum and distribution of Calodium hepaticum (syn. Capillaria hepatica): part 2Mammalia (excluding Muroidea). Parasitol Res. (accepted)

Gallego Berenguer J (1959) Parasitismo vermidiano de los múridos españoles. Revista de sanidad e higiene publica 33, 169-208. In: Schmidt S (2001) Untersuchungen zum Vorkommen von Capillaria hepatica und Metazestoden der Cyclophyllida bei Wildmäusen in Deutschland. PhD Thesis, Universität., Veterinärmedizinische Fakultät, Leipzig:145pp.

Galvão VA (1981) Estudos sobre Capillaria hepatica: uma avaliação do seu papel patogênico para o homen. Mem Inst Oswaldo Cruz 76(4): 415-433

Genov T (1984) Helminths of insectivores and rodents in Bulgaria. Publishing House of the Bulgarian Academy of Sciences, Sofia, Bulgaria: pp 348. In: Asakawa M, Tenora F (1996) A checklist of nematode parasites of the genus Apodemus (Murinae: Rodentia) throughout the world excluding Japan. J. Rakuno Gakuen Univ 20 (2): $181-213$

Ghelardoni E (1966) Infestione da Capillaria hepatica (BANCROFT, 1893) nei muridi della provincia di Pisa. Ann Fac Medic Vet di Parma 18: 91-100. In: Schmidt S (2001) Untersuchungen zum Vorkommen von Capillaria hepatica und Metazestoden der Cyclophyllida bei Wildmäusen in Deutschland. PhD Thesis, Universität., Veterinärmedizinische Fakultät, Leipzig:145pp.

Guardone L, Deplazes P, Macchioni F, Magi M, Mathis A (2013) Ribosomal and mitochondrial DNA analysis of Trichuridae nematodes of carnivores and small mammals. Vet Parasitol. doi:10.1016/ j.vetpar.2013.06.022

Hall MC (1916) Nematode parasites of mammals of the orders Rodentia, Lagomorpha and Hyracoidea. Proc US Natl Mus 50:1-258

Hancke D (2011) Endoparasitos de Rattus norvegicus en un ambiente urbano marginal de la ciudad de Buenos Aires. Mastozool Neotrop 18(1):147-148

Harkema R (1936) The parasites of some North Carolina rodents. Ecol Monogr. 6: 153-232. In: Lubinsky G (1956) On the probable presence of parasitic liver cirrhoses in Canada. Can J Comp Med Vet Sci. 20: 457-465

Herman CM (1939) A parasitological survey of wild rats in New York Zoological Park. Zoologica 24: 305-308. In: Lubinsky G (1956) On the probable presence of parasitic liver cirrhoses in Canada. Can J Comp Med Vet Sci. 20: 457-465

Herman TB (1981) Capillaria hepatica (Nematoda) in insular populations of deer mouse Peromyscus maniculatus: Cannibalism or competition for carcasses? Can J Zool. 59: 776-784. In: Schmidt S (2001) Untersuchungen zum Vorkommen von Capillaria hepatica und Metazestoden der Cyclophyllida bei Wildmäusen in Deutschland. PhD Thesis, Universität., Veterinärmedizinische Fakultät, Leipzig:145pp.

Hörning B (1966) Die Helminthenfauna der Nagetiere (Rodentia, Simplicidentia) der Paläarktis, unter Berücksichtigung ihrer Faunistik und ihrer Übertragungsmöglichkeiten auf den Menschen 
und auf Haustiere. Bern, Univ., Veterinärmed. Fakultät, Habil.Schr. In: Schmidt S (2001) Untersuchungen zum Vorkommen von Capillaria hepatica und Metazestoden der Cyclophyllida bei Wildmäusen in Deutschland. PhD Thesis, Universität., Veterinärmedizinische Fakultät, Leipzig:145pp.

Ishimoto Y (1974) Studies on helminths of voles in Hokkaido. I. Taxonomical study. Jpn J Vet Res. 22: 1-12. In: Schmidt S (2001) Untersuchungen zum Vorkommen von Capillaria hepatica und Metazestoden der Cyclophyllida bei Wildmäusen in Deutschland. $\mathrm{PhD}$ Thesis, Universität., Veterinärmedizinische Fakultät, Leipzig: $145 \mathrm{pp}$.

Ito A, Okamoto M, Kariwa H, Ishiguro T, Hashimoto A, Nakao M (1996) Antibody responses against Echinococcus multilocularis antigens in naturally infected Rattus norvegicus. J Helminthol. 70: 355-357. In: Schmidt S (2001) Untersuchungen zum Vorkommen von Capillaria hepatica und Metazestoden der Cyclophyllida bei Wildmäusen in Deutschland. PhD Thesis, Universität., Veterinärmedizinische Fakultät, Leipzig:145pp.

Iwaki T, Hatakeyama S, Nonaka N, Miyaji S, Yokohata Y, Okamoto M, Ooi HK, Oku Y, Kamiya M (1993) Survey on larval Echinococcus multilocularis and other hepatic helminths in rodents and insectivores in Hokkaido, Japan, from 1985 to 1992. Jpn J Parasitol. 42: 502-506. In: Schmidt S (2001) Untersuchungen zum Vorkommen von Capillaria hepatica und Metazestoden der Cyclophyllida bei Wildmäusen in Deutschland. PhD Thesis, Universität., Veterinärmedizinische Fakultät, Leipzig:145pp.

Joyeux C, Gendre E, Baer JG (1928) Recherches sur les Helminthes de l'Afrique occidentale francaise. Coll. Soc. Path. Exot., Monographie II, Paris, Masson. In: Justine JL (1989) Liste des Capillaria (Nematoda, Capillariinae) parasites de Mammiferes africains. Bull. Mus. Natn. Hist. Nat. Paris, 11(4): 755-762

Juncker M, Kübber-Heiss A, Prosl H (1998) Zum Vorkommen von Capillaria hepatica bei Hausmäusen (Mus musculus) in Österreich. Mitt Österr Ges Tropenmed Parasitol 20:137-142

Juncker-Voss M, Prosl H, Lussy H, Enzenberg U, Auer H, Nowotny N (2000) Serological detection of Capillaria hepatica by indirect immunofluorescence assay. J Clin Microbiol 38(1):431-3, Review

Kamiya M, Chinzei H, Sasa M (1968) A survey on helminth parasites of rats in southern Amamai, Japan. Jap. J. Parasit. 17(5): 74-82. In: Seo BS, Rim HJ, Yoon JJ, Koo BY, Hong NT (1968) Studies on the parasitic helminths of Korea III. Nematodes and cestodes of rodents. Korean J Parasitol. 6(3): 123-131

Kataranovski M, Zolotarevski L, Belij S, Mirkov I, Stošić J, Popov A, Kataranovski D (2010) First record of Calodium hepaticum and Taenia taeniaeformis liver infection in wild Norway rats (Rattus norvegicus) in Serbia. Arch Biol Sci Belgrade 62(2):431-440

Kia E, Shahryary-Rad E, Mohebali M, Mahmoudi M, Mobedi I, Zahabiun F, Zarei Z, Miahipoor A, Mowlavi G, Akhavan A, Vatandoost $H$ (2010) Endoparasites of rodents and their zoonotic importance in Germi, Dashte-Mogan, Ardabil Province, Iran. Iran J Parasitol 5(4):15-20

King GL, Stanton G (1974) Modification of the epizootiology of Capillaria hepatica by the host type infected. Bulletin of the Georgia Academy of Science 32: 3. In: Schmidt S (2001) Untersuchungen zum Vorkommen von Capillaria hepatica und Metazestoden der Cyclophyllida bei Wildmäusen in Deutschland. PhD Thesis, Universität., Veterinärmedizinische Fakultät, Leipzig:145pp.

Kinsella JM (1974) Comparison of helminth parasites of the Cotton Rat, Sigmodon hispidus, from several habitats in Florida. Am Mus Novit 2540:1-11

Kirakosjan MO, Lusararjan VS, Davtjan GG, Sakanjan AB (1963) K obnaruženiju novych chozjaev dlja Capillaria hepatica v Armenii. Izvestija Akademii Nauk Armjankoj SSR / Biologiceskie nauki 16: 95-97

Kirschenblat ID (1948) Материатык гел минтофауне грыэунов Груэии. Trud. Trud. Zool. Inst. Georg. 8: 317-339. In: Asakawa
M, Tenora F (1996) A checklist of nematode parasites of the genus Apodemus (Murinae: Rodentia) throughout the world excluding Japan. J. Rakuno Gakuen Univ 20 (2): 181-213

Kirschenblatt JD (1938) Die Gesetzmässigkeiten der Dynamik der Parasitenfauna bei den maeuseähnlichen Nagetieren (Muriden) in Transkaukasien. Diss. Univ. Leningrad: pp. 592

Koval'chuk ES, Bonina OM (1981) A focus Hepaticola hepatica infection in the Barabin lowlands. In: Asakawa M, Tenora F (1996) A checklist of nematode parasites of the genus Apodemus (Murinae: Rodentia) throughout the world excluding Japan. J. Rakuno Gakuen Univ 20(2): 181-213

Kumar V, Brandt J, Mortelmans J (1985) Hepatic capillariasis may simulate the syndrome of visceral larva migrans, an analysis. Ann Soc Belg Med Trp. 65: 101-104. In: Schmidt S (2001) Untersuchungen zum Vorkommen von Capillaria hepatica und Metazestoden der Cyclophyllida bei Wildmäusen in Deutschland. $\mathrm{PhD}$ Thesis, Universität., Veterinärmedizinische Fakultät, Leipzig: $145 \mathrm{pp}$.

Lagrange ME (1924) Sur un Trichocéphalidé du ratt á Sanghai, Hepaticola hepatica HALL, 1916. B Soc Pathol Exot. 17: 658659. In: Schmidt S (2001) Untersuchungen zum Vorkommen von Capillaria hepatica und Metazestoden der Cyclophyllida bei Wildmäusen in Deutschland. PhD Thesis, Universität., Veterinärmedizinische Fakultät, Leipzig:145pp.

Layne JN (1968) Host and ecological relationships of the parasitic helminth Capillaria hepatica in Florida mammals. Zoologica 53: 107123. In: Schmidt S (2001) Untersuchungen zum Vorkommen von Capillaria hepatica und Metazestoden der Cyclophyllida bei Wildmäusen in Deutschland. PhD Thesis, Universität., Veterinärmedizinische Fakultät, Leipzig:145pp.

Layne JN, Griffo JV Jr (1961) Incidence of Capillaria hepatica in populations of the Florida deer mouse. Peromyscus floridanus. J Parasitol 47:31-37

Layne JN (1970) New host records of Capillaria hepatica in Florida. Fla Sci. 33: 18-22. In: Schmidt S (2001) Untersuchungen zum Vorkommen von Capillaria hepatica und Metazestoden der Cyclophyllida bei Wildmäusen in Deutschland. PhD Thesis, Universität., Veterinärmedizinische Fakultät, Leipzig:145pp.

Layne JN, Winegarner CE (1971) Occurrence of Capillaria hepatica (Nematoda: Trichuridae) in the spotted skunk in Florida. J Wildl Dis 7(4):256-7

Leon de DD (1964) Helminth parasites of rats in San Juan, Puerto Rico. J Parasitol. 50: 478-479. In: Schmidt S (2001) Untersuchungen zum Vorkommen von Capillaria hepatica und Metazestoden der Cyclophyllida bei Wildmäusen in Deutschland. PhD Thesis, Universität., Veterinärmedizinische Fakultät, Leipzig:145pp.

Lewis JW (1968) Studies on the helminth parasites of the long-tailed field mouse, Apodemus sylvaticus sylvaticus, from Wales. J Zool. 154: 287-312. In: Lloyd S, Elwood CM, Smith KC (2002) Capillaria hepatica (Calodium hepaticum) infection in a British dog. Vet Rec. 151(14):419-20

Liat LB, Fong YL, Krishnasamy M (1977) Capillaria hepatica infection of wild rodents in Peninsular Malaysia. Southeast Asian J Trop Med Public Health 8: 354-358. In: Schmidt S (2001) Untersuchungen zum Vorkommen von Capillaria hepatica und Metazestoden der Cyclophyllida bei Wildmäusen in Deutschland. $\mathrm{PhD}$ Thesis, Universität., Veterinärmedizinische Fakultät, Leipzig:145pp.

Lin XM, Xu BL, Zhao XD, Li H, Huang Q, Deng Y, Hao ZY, Zhang AM (2007) Epidemiological investigation on Capillaria hepatica infection among little animal in Henan Province. Zhongguo Jishengchoubing Fangzhi Zazhi 2: 44-46. In: Li CD, Yang HL, Wang Y (2010) Capillaria hepatica in China. World J Gastroenterol. 16(6):698-702 
Lubinsky G (1956) On the probable presence of parasitic liver cirrhoses in Canada. Can J Comp Med Vet Sci 20:457-465

Lubinsky G (1957) List of helminths from Alberta rodents. Can J Zool. 35: 623-627. In: Schmidt S (2001) Untersuchungen zum Vorkommen von Capillaria hepatica und Metazestoden der Cyclophyllida bei Wildmäusen in Deutschland. PhD Thesis, Universität., Veterinärmedizinische Fakultät, Leipzig:145pp.

Lubinsky G, Jacobsen BR, Baron RW (1971) Wildlife foci of Capillaria hepatica infections in Manitoba. Can J Zool. 49: 1201-1202. In: Schmidt S (2001) Untersuchungen zum Vorkommen von Capillaria hepatica und Metazestoden der Cyclophyllida bei Wildmäusen in Deutschland. PhD Thesis, Universität., Veterinärmedizinische Fakultät, Leipzig:145pp.

Luttermoser GW (1936) A helminthological survey of Baltimore house rats (Rattus norvegicus). Amer. J. Hyg. 24(2): 350-360. In: Seo BS, Rim HJ, Lee CW, Yoon JS (1964) Studies on the parasitic helminths of Korea: II. Parasites of the rat, Rattus norvegicus Erxl. In Seoul, with the description of Capillaria hepatica (Bancroft, 1893) Travassos, (1915). Kisaengchunghak Chapchi. 2(1):55-62

Luttermoser GW (1937) Resistance of rats and mice to infection with Capillaria hepatica . (American Society of Parasitologists, Program and abstracts of the thirteenth annual meeting). J. Parasitol. 23: 547574. In: Schmidt S (2001) Untersuchungen zum Vorkommen von Capillaria hepatica und Metazestoden der Cyclophyllida bei Wildmäusen in Deutschland. PhD Thesis, Universität., Veterinärmedizinische Fakultät, Leipzig:145pp.

Luttermoser GW (1938) An experimental study of Capillaria hepatica in the rat and the mouse. The Am J Hyg 27:321-340

Malekani M (1990) Studies on hepatic capillariasis and on the genus Meggittina (Cestoda) of Cricetomys spp.;- - some of the edible rodents in Zaire. Antwerp: Prince Leopold Institute of Tropical Medicine (M.Sc. Thesis): pp136.

Malekani M, Kumar V, Pandey VS (1994) Hepatic capillariasis in edible Cricotomys spp. (Rodentia: Cricetidae) in Zaire and its possible public health implication. Ann Trop Med Parasit 88:569-572

Malsawmtluangi C, Tandon V (2009) Helminth parasite spectrum in rodent hosts from bamboo growing areas of Mizoram, Northeast India. J Parasit Dis 33(1-2):28-35. doi:10.1007/s12639-0090004-5

Mascato FA, Rey J, Bos J, Peris D, Paniagua E, Blanco P (1993) Parasitos Capillariinae (Nematoda) de algunas especies de micromamiferos gallegos. NACC-Bioloxia 4:111-120

Mas-Coma S, Feliu C (1977) Contribucion al conocimiento de la helmintofauna de micromamiferos Ibericos. IV. Parasitos de Apodemus sylvaticus LINNAEUS, 1978 (Rodentia, Muridae). Revista iberica de parasitologia 37:301-317

Meagher S (1998) Physiological responses of deer mice (Peromyscus maniculatus) to infection with Capillaria hepatica (Nematoda). J Parasitol 84:1112-1118

Merdivenci A (1970) Türkiye'de Hepaticola hepatica infeksiyonlari ve parazitin gelisimi üzerine bazi deneyler. Istanbul Ueniversitesi Tip Fakueltesi mecmuasi 32: 423-436. In: Schmidt S (2001) Untersuchungen zum Vorkommen von Capillaria hepatica und Metazestoden der Cyclophyllida bei Wildmäusen in Deutschland. $\mathrm{PhD}$ Thesis, Universität., Veterinärmedizinische Fakultät, Leipzig: $145 \mathrm{pp}$.

Mészáros J, Kemenes F (1973) Capillaria hepatica verursachte Hepatitis bei einem Biber (Castor fiber). Parasitol Hung 6:33-40

Meyers MC, Reilly JR (1950) Parasites of muskrats in Maine. Amer Midland Nat 44:467-477

Milazzo C, Cagnin M, Di Bella C, Geraci F, Ribas A (2010a) Helminth fauna of commensal rodents, Mus musculus (Linnaeus, 1758) and Rattus rattus (Linnaeus, 1758) (Rodentia, Muridae) in Sicily (Italy). Rev Ibero-Latinoam Parasitol 69(2):194-198

Milazzo C, Ribas A, Casanova JC, Cagnin M, Geraci F, Di Bella C (2010b) Helminths of the brown rat (Rattus norvegicus)
(Berkenhout, 1769) in the city of Palermo, Italy. Helminthologia 47(4):238-240

Min HK (1979) Prevalence of Capillaria hepatica among house rat in Seoul. Korean J Parasitol 17(2):93-97

Mishra GS, Gonzalez JP (1975) Bilan d'une etude sur les endoparasites du rat, Rattus norvegicus Berkenhout, 1769, à Tunis. Archs Inst. Pasteur Tunis, 52: 71-87. In: Justine JL (1989) Liste des Capillaria (Nematoda, Capillariinae) parasites de Mammiferes africains. Bull. Mus. Natn. Hist. Nat. Paris, 11(4): 755-762

Mituch J (1960) Zur Verbreitung der Helminthen bei der Nordischen Ratte (Rattus norvegicus ERXL.) in der Slowakei.Helminthologia 2: 114-132. In: Schmidt S (2001) Untersuchungen zum Vorkommen von Capillaria hepatica und Metazestoden der Cyclophyllida bei Wildmäusen in Deutschland. PhD Thesis, Universität., Veterinärmedizinische Fakultät, Leipzig:145pp.

Mituch J (1966/1970) Helmontofauna drobnych cicavcov a mäsožravcov TANAP. In Report of Helminthological Institute Slovak Academy of Sciences, Košice: 85-117. In: Asakawa M, Tenora F (1996) A checklist of nematode parasites of the genus Apodemus (Murinae: Rodentia) throughout the world excluding Japan. J. Rakuno Gakuen Univ 20 (2): 181-213

Mobedi II, Arfaa F (1971) Probable role of ground beetles in the transmission of Capillaria hepatica. J. Parasitol. 57: 11441145. In: Asakawa M, Tenora F (1996) A checklist of nematode parasites of the genus Apodemus (Murinae: Rodentia) throughout the world excluding Japan. J. Rakuno Gakuen Univ 20 (2): 181-213

Momma K (1930) Notes on modes of rat infestation with Hepaticola hepatica. Ann. Trop. Med. and Parasitol. 24(1): 109-113. In: Seo BS, Rim HJ, Lee CW, Yoon JS (1964) Studies on the parasitic helminths of Korea: II. Parasites of the rat, Rattus norvegicus Erxl. In Seoul, with the description of Capillaria hepatica (Bancroft, 1893) Travassos, (1915). Kisaengchunghak Chapchi. 2(1):55-62

Moravec F (1982) Proposal of a new systematic arrangement of nematodes of the family Capillariidae. Folia Parasitol (Praha) 29(2):119 32

Moreira VLC, Giese EG, da Silva DCB, de Vasconcelos Melo FT, Furtado AP, Maldonado A Jr, dos Santos JN (2013) Calodium hepaticum (Nematoda: Capillariidae) in synanthropic rodents (Rattus norvegicus and Rattus rattus) in Eastern Amazonia. Rev Bras Parasitol Vet Jaboticabal 22(2):265-269

Morozow JUF (1956) K poznaniju gel'mintofauny gryzunov i nasekomojadnych SSSR i opyt ee ekologo-geografifeskogo analiza. Diss. biol. Wiss. In: Schmidt S (2001) Untersuchungen zum Vorkommen von Capillaria hepatica und Metazestoden der Cyclophyllida bei Wildmäusen in Deutschland. PhD Thesis, Universität., Veterinärmedizinische Fakultät, Leipzig:145pp.

Mulkit S, Cheong CH (1971) On a collection of nematode parasites from Malayan rats. Southeast Asian J Trop Med Public Health 2: 516 522. In: Schmidt S (2001) Untersuchungen zum Vorkommen von Capillaria hepatica und Metazestoden der Cyclophyllida bei Wildmäusen in Deutschland. PhD Thesis, Universität., Veterinärmedizinische Fakultät, Leipzig:145pp.

Nakamura K, Kobashi S (1935) Die Arten der Ratten in Chosen (insbesondere in Keijo und Jinsen) und die bei ihnen gefundenen Ekto- sowie Entoparasiten. Jour. Chosen Med. Assoc. 25(5): 183184. In: Seo BS, Rim HJ, Lee CW, Yoon JS (1964) Studies on the parasitic helminths of Korea: II. Parasites of the rat, Rattus norvegicus Erxl. In Seoul, With the description of Capillaria hepatica (Bancroft, 1893) Travassos, (1915). Kisaengchunghak Chapchi. 2(1):55-62

Namue C, Wongsawad C (1997) A survey of helminth infection in rats (Rattus spp) from Chiang Mai Moat. Southeast Asian. J Trop Med Public Health 28(Suppl 1):179-83

Onyenwe IW, Ihedioha JI, Ezeme RI (2009) Prevalence of zoonotic helminths in local house rats (Rattus rattus) in Nsukka, Eastern Nigeria. Animal Research International 6(3):1040-1044 
Owen D (1976) Some parasites and other organisms of wild rodents in the vicinity of an SPF unit. Lab Anim 10(3):271-8

Pakdel N, Naem S, Rezaei F, Chalehchaleh AA (2013) A survey of helminth infection in mice (Mus musculus) and rats (Rattus norvegicus and Rattus rattus) in Kermanshah, Iran. Vet Res Forum 4(2):105-109

Paperna I, Furman DP, Rothstein N (1970) The parasite fauna of rodents from urban and suburban areas of Accra-Tema, South Ghana. Revue Zool. Bot. Afr. 81: 330-336. In: Justine JL (1989) Liste des Capillaria (Nematoda, Capillariinae) parasites de Mammiferes africains. Bull. Mus. Natn. Hist. Nat. Paris, 11(4): 755-762

Paramasvaran S, Sani RA, Hassan L, Hanjeet K, Krishnasamy M, John J, Santhana R, Sumarni MG, Lim KH (2009) Endo-parasite fauna of rodents caught in five wet markets in Kuala Lumpur and its potential zoonotic implications. Trop Biomed 26(1):67-72

Pasricha CL, Panja G, Bhaduri NV (1941) Capillaria hepatica in a wild rat in Calcutta. Ind Med Gaz. 76, 475-476. In: Schmidt S (2001) Untersuchungen zum Vorkommen von Capillaria hepatica und Metazestoden der Cyclophyllida bei Wildmäusen in Deutschland. $\mathrm{PhD}$ Thesis, Universität., Veterinärmedizinische Fakultät, Leipzig: $145 \mathrm{pp}$.

Patel AK, Bhattachaiya D, Chattopadhyay UK, Bera AK, Sikdar A (2004) Capillariasis in rats: prevalence and pathological evaluation. J. Vet. Parasitol. 111: 89-90. In: Goswami R (2012) Studies on comparative heamato-biochemical profile in certain spontaneously occurring helminths in wild and laboratory rats. $\mathrm{PhD}$ Thesis, Mahatma Jyotiba Rohilkhand University Bareilly (U.P.), India. pp 219.

Pavlov AV (1955) Biologija nematody Hepaticola hepatica i osobennosti epizootologii vyzyvaemogo eju zabolebanija pu,nych zverej. Moskau, Avtorref. dis. kand. biol. nauk. 27. In: Schmidt S (2001) Untersuchungen zum Vorkommen von Capillaria hepatica und Metazestoden der Cyclophyllida bei Wildmäusen in Deutschland. $\mathrm{PhD}$ Thesis, Universität., Veterinärmedizinische Fakultät, Leipzig: $145 \mathrm{pp}$.

Penn GH (1952) Parasitology survey of Louisiana muskrats. J Parasitol. 28: 348-349. In: Borucinska JD, Nielsen SW (1993) Hepatic capillariasis in muskrats (Ondatra zibethicus). J Wildl Dis. 29, 518-520

Pereira VMM (2009) Estudo da helmintofauna de Mus musculus (Rodentia) em São Miguel (Açores): fatores indutores de diversidade e potencial zoonótico. Dissertação de Mestrado em Biologia Humana e Ambiente. Lisboa: Faculdade de CiênciasUniversidade de Lisboa. In: Crespo APMAM (2012) Controlo de pragas no jardim zoológico de Lisboa particular relevância para o controlo de roedores e sua infeção parasitária. Dissertação de Mestrad em Segurança Alimentar. Faculdade de Medicina Veterinária. Universidade Técnica de Lisboa. pp. 174

Perugia A (1893) Sul Trichosoma del fegato dei Muridi. Atti della Societa Ligustica di Scienze Naturali e Geografiche 4: 206-210. In: Schmidt S (2001) Untersuchungen zum Vorkommen von Capillaria hepatica und Metazestoden der Cyclophyllida bei Wildmäusen in Deutschland. PhD Thesis, Universität., Veterinärmedizinische Fakultät, Leipzig:145pp.

Pleščëv VS, Kozlov AN (1978) Gel'mintofauna sinantropnych gryzunov celinogradskoj oblasti. Materialy naučnych konferencij vsesojuznogo obščestva gel'mintologov 30: 135-139. In: Schmidt S (2001) Untersuchungen zum Vorkommen von Capillaria hepatica und Metazestoden der Cyclophyllida bei Wildmäusen in Deutschland. PhD Thesis, Universität., Veterinärmedizinische Fakultät, Leipzig:145pp.

Price EW (1931) Hepaticola hepatica in liver of Ondatra zibethica. J Parasitol. 18: 44-56. In: Borucinska JD, Nielsen SW (1993) Hepatic capillariasis in muskrats (Ondatra zibethicus). J Wildl Dis. 29: 518 520

Price EW and Chitwood BG (1931) Incidence of internal parasites in wild rats in Washington, D.C. J. Parasit. 18:51. In: Lubinsky G (1956) On the probable presence of parasitic liver cirrhoses in Canada. Can J Comp Med Vet Sci. 20: 457-465

Prokopič J, Genov T (1974) Distribution of helminths in micromammals (Insectivora and Rodentia) under different ecological and geographical conditions. Studie ČSAV. 9: 1-159. In: Asakawa M, Tenora F (1996) A checklist of nematode parasites of the genus Apodemus (Murinae: Rodentia) throughout the world excluding Japan. J. Rakuno Gakuen Univ 20 (2): 181-213

Prokopič J, Tenora F (1975) Contribution to the knowledge of helminth fauna of small mammals in Spain. Vestnik Ceskoslovenske Spolecnosti Zoologicke 39: 60-67. In: Schmidt S (2001) Untersuchungen zum Vorkommen von Capillaria hepatica und Metazestoden der Cyclophyllida bei Wildmäusen in Deutschland. PhD Thesis, Universität., Veterinärmedizinische Fakultät, Leipzig:145pp.

Rausch R (1961) Notes on the occurrence of Capillaria hepatica (BANCROFT, 1893). P Helm Soc Wash. 28: 17-18. In: Schmidt S (2001) Untersuchungen zum Vorkommen von Capillaria hepatica und Metazestoden der Cyclophyllida bei Wildmäusen in Deutschland. PhD Thesis, Universität., Veterinärmedizinische Fakultät, Leipzig:145pp.

Read CP (1949) Studies on North American helminths of the genus Capillaria ZEDER, 1800 (Nematoda): I. Capillarids from mammals. J Parasitol 35:223-230

Redrobe SP, Patterson-Kane JC (2005) Calodium hepaticum (syn. Capillaria hepatica) in captive rodents in a zoological garden. J Comp Pathol 133(1):73-6

Reperant LA, Deplazes P (2005) Cluster of Capillaria hepatica infections in non-commensal rodents from the canton of Geneva, Switzerland. Parasitol Res 96(5):340-2

Resendes AR, Amaral AF, Rodrigues A, Almeria S (2009) Prevalence of Calodium hepaticum (Syn. Capillaria hepatica) in house mice (Mus musculus) in the Azores archipelago. Vet Parasitol 160(3-4): 340-3. doi:10.1016/j.vetpar.2008.11.001

Roberts M (1990) The ecological parasitology of the Polynesian rat (Rattus exulans) on Tiritiri Matangi Island. Unpublished Ph.D. thesis. University of Auckland, Auckland, New Zealand. In: McKenna PB (1997) Checklist of helminth parasites of terrestrial mammals in New Zealand. New Zeal J Zool. 24:277-90.

Rojas A, Villarroel F, Diaz F, Rubio P, Schenone H (1971) Investigación de triquinosis y capilariasis hepática en Rattus norvegicus del Matadero Municipal de Santiago (Chile). Bol Chil Parasitol. 26: 65-66. In: Schmidt S (2001) Untersuchungen zum Vorkommen von Capillaria hepatica und Metazestoden der Cyclophyllida bei Wildmäusen in Deutschland. PhD Thesis, Universität., Veterinärmedizinische Fakultät, Leipzig:145pp.

Romašov BV (1978) Biotopičeskoe raspredelenie nematody Hepaticola hepatica (Capillariidae) i sezonnaja dinamika zaražennosti eju melkich mlekopitaju,čich voronežskogo zapovednika. Materialy nauchnych konferencij vsesojuznogo obscestva gel'mintologov 30: 139-147. In: Asakawa M, Tenora F (1996) A checklist of nematode parasites of the genus Apodemus (Murinae: Rodentia) throughout the world excluding Japan. J. Rakuno Gakuen Univ 20 (2): 181-213

Romašov BV (1983) Osobennosti žiznennogo cikla Hepaticola hepatica (Nematoda, Capillariidae). In: Parazitologičeskie issledovanija v zapovednikach (Sbornik Naučnych Trudov Central'naja naučnoissledovatel'skaja laboratorija ochotnič'ego chozjajstva i zapovednikov) Moskau, S. 49-58.

Romašov BV (1995) Ekologija parazitičeskoj nematody Calodium hepaticum (Nematoda: Capillariidae) Voronežskij Biosphernyj Zapovednik. Sostojanie i problemy ekosystem srednego podon'ja. Trudy biologiceskoj učebno-naučnoj bazy Voronežkogo gosudarstvennogo universiteta "Venevitinovo" 7, 44-50. In: Schmidt S (2001) Untersuchungen zum Vorkommen von Capillaria hepatica und Metazestoden der Cyclophyllida bei Wildmäusen in Deutschland. PhD Thesis, Universität., Veterinärmedizinische Fakultät, Leipzig:145pp. 
Romašov BV (1996) Ecological connections in life cycle Capillaria hepatica (BANCROFT, 1893) (Nematoda: Trichocephalida). Abstracts VII European Multicolloquium of Parasitology (EMOP VII) 1996. Parassitologia 38, 20. In: Schmidt S (2001) Untersuchungen zum Vorkommen von Capillaria hepatica und Metazestoden der Cyclophyllida bei Wildmäusen in Deutschland. PhD Thesis, Universität., Veterinärmedizinische Fakultät, Leipzig: $145 \mathrm{pp}$.

Roque MM, Mendonça MM, Marcos MV, Lopes FJ (1984) Endoparasitas encontrados no rato cinzento (Rattus norvegicus Berk.) da zona de Lisboa. Revista Portuguesa de Doenças Infeciosas 7(2): 101-109. In: Crespo APMAM (2012) Controlo de pragas no jardim zoológico de Lisboa particular relevância para o controlo de roedores e sua infeção parasitária. Dissertação de Mestrad em Segurança Alimentar. Faculdade de Medicina Veterinária. Universidade Técnica de Lisboa. pp. 174

Roque MM (1989) Fauna helmintológica de vertebrados terrestres da Ilha de S. Miguel (Açores). Dissertação de Doutoramento em Biologia. Universidade dos Açores. In: Crespo APMAM (2012) Controlo de pragas no jardim zoológico de Lisboa particular relevância para o controlo de roedores e sua infeção parasitária. Dissertação de Mestrad em Segurança Alimentar. Faculdade de Medicina Veterinária. Universidade Técnica de Lisboa. pp. 174

Rupeš V (1964) Parasitičtí červi u Apodemus flavicollis a Clethrionomys glareolus z okolí Prahy. Çeskoslovenská parazitologie 11: 335-338. In: Schmidt S (2001) Untersuchungen zum Vorkommen von Capillaria hepatica und Metazestoden der Cyclophyllida bei Wildmäusen in Deutschland. PhD Thesis, Universität., Veterinärmedizinische Fakultät, Leipzig:145pp.

Rydlo M (1966): Beitrag zur Kenntnis der Parasitenfauna der Wanderratte Rattus norvegicus (BERKENHOUT, 1769).- Wien, Univ., Philosoph. Fak., Diss.

Sandground JH (1933) Parasitic nematodes from East Africa and Southern Rhodesia. Bull Mus Comp Zool Harvard Univ. 75: 263293. In: Schmidt S (2001) Untersuchungen zum Vorkommen von Capillaria hepatica und Metazestoden der Cyclophyllida bei Wildmäusen in Deutschland. PhD Thesis, Universität., Veterinärmedizinische Fakultät, Leipzig:145pp.

Sato A, Shimatani T (1960) Studies on Capillaria hepatica. I. Incidence of $C$. hepatica of house rats Kyoto and Maizuru cities, Kyoto Prefecture. Medicine and biology 57: 181-183. (Japanese) In: Schmidt S (2001) Untersuchungen zum Vorkommen von Capillaria hepatica und Metazestoden der Cyclophyllida bei Wildmäusen in Deutschland. PhD Thesis, Universität., Veterinärmedizinische Fakultät, Leipzig:145pp.

Scandola P, de Biasi C, Davoust B, Marié JL (2013) Prevalence of Capillaria hepatica in non-commensal rodents from a forest area near Dijon, France. Parasitol Res 112(7):2741-4. doi:10.1007/ s00436-013-3369-4

Schmidt S, Haupt W, Ribbeck R (1998) Capillaria hepatica - ein seltener Zoonose-Erreger. Vorkommen bei Mäusen Mitt Österr Ges Tropenmed Parasitol 20:131-136

Schmidt S (2001) Untersuchungen zum Vorkommen von Capillaria hepatica und Metazestoden der Cyclophyllida bei Wildmäusen in Deutschland. PhD Thesis, Universität., Veterinärmedizinische Fakultät, Leipzig:145pp.

Schwetz J (1956) Role of wild rats and domestic rats (Rattus rattus) in schistosomiasis of man. T Roy Soc Trop Med H. 50: 275-282. In: Schmidt S (2001) Untersuchungen zum Vorkommen von Capillaria hepatica und Metazestoden der Cyclophyllida bei Wildmäusen in Deutschland. PhD Thesis, Universität., Veterinärmedizinische Fakultät, Leipzig:145pp.

Seo BS, Rim HJ, Lee CW, Yoon JS (1964) Studies on the parasitic helminths of Korea: II. Parasites of the rat, Rattus norvegicus Erxl. In Seoul, with the description of Capillaria hepatica (Bancroft, 1893) Travassos, (1915). Kisaengchunghak Chapchi. 2(1):55-62
Seo BS, Rim HJ, Yoon JJ, Koo BY, Hong NT (1968) Studies on the parasitic helminths of Korea III. Nematodes and cestodes of rodents. Korean J Parasitol 6(3):123-131

Seong JK, Huh S, Lee JS, Oh YS (1995) Helminths in Rattus norvegicus captured in Chunchon, Korea. Korean J Parasitol 33:235-237

Sharma D, Joshi S, Vatsya S, Yadav CL (2012) Prevalence of gastrointestinal helminth infections in rodents of Tarai region of Uttarakhand. J Parasit Dis.: 1-4.

Shen LJ, Luo ZY, Li W, Li ZH, Gao C, Yang WB, Li LY, Qian TJ (2003) Investigation on rats infected with Capillaria hepatica in Dali. Zhongguo Jishengchoubing Fangzhi Zazhi 16: 296-298. In: Li CD, Yang HL, Wang Y (2010) Capillaria hepatica in China. World J Gastroenterol. 16(6):698-702

Shimatani T (1961) Studies on the ecology of Capillaria hepatica eggs. Journal of Kyoto Prefectural Medical University 69: 1063-1083. Japanese. In: Schmidt S (2001) Untersuchungen zum Vorkommen von Capillaria hepatica und Metazestoden der Cyclophyllida bei Wildmäusen in Deutschland. PhD Thesis, Universität., Veterinärmedizinische Fakultät, Leipzig:145pp.

Shorb DA (1931) Experimental infestation of white rats with Hepaticola hepatica. J Parasitol. 17: 151-154. In: Schmidt S (2001) Untersuchungen zum Vorkommen von Capillaria hepatica und Metazestoden der Cyclophyllida bei Wildmäusen in Deutschland. $\mathrm{PhD}$ Thesis, Universität., Veterinärmedizinische Fakultät, Leipzig: $145 \mathrm{pp}$.

Simmons DJC, Walkey M (1971) Capillaria and Hymenolepis in a wild rat: hazards to barrier-maintained laboratory animals. Lab Anim 5:49-55

Singla N, Singla LD, Gupta K, Sood NK (2013) Pathological alterations in natural cases of Capillaria hepatica infection alone and in concurrence with Cysticercus fasciolaris in Bandicota bengalensis. J Parasit Dis 37(1):16-20

Singleton GR, Spratt DM, Barker SC, Dodgson PF (1991) The geographic distribution and host range of Capillaria hepatica (BANCROFT) (Nematoda) in Australia. Int J Parasitol 21:945-957

Singleton GR, Chambers LK (1996) A manipulative field experiment to examine the effect of Capillaria hepatica (Nematoda) on wild mouse populations in southern Australia. Int J Parasitol 26:383-398

Sinniah B, Singh M, Anuar K (1979) Preliminary survey of Capillaria hepatica (BANCROFT, 1893) in Malaysia. J Helminthol 53:147152

Solomon GB, Handley CO (1971) Capillaria hepatica (Bancroft, 1893) in Appalachian mammals. J Parasitol 57(5):1142-4

Somvanshi R, Bhattacharya D, Laha R, Rangarao GSC (1995) Spontaneous Capillaria hepatica infestation in wild rats (Rattus rattus). Indian J Vet Pathol. 19, 44-45. In: Schmidt S (2001) Untersuchungen zum Vorkommen von Capillaria hepatica und Metazestoden der Cyclophyllida bei Wildmäusen in Deutschland. $\mathrm{PhD}$ Thesis, Universität., Veterinärmedizinische Fakultät, Leipzig: $145 \mathrm{pp}$.

Spratt DM, Singleton GR (1986) Studies on the life cycle, infectivity and clinical effects of Capillaria hepatica (BANCROFT) (Nematoda) in mice, Mus musculus. Aust J Zool. 34: 663-675. In: Schmidt S (2001) Untersuchungen zum Vorkommen von Capillaria hepatica und Metazestoden der Cyclophyllida bei Wildmäusen in Deutschland. PhD Thesis, Universität., Veterinärmedizinische Fakultät, Leipzig:145pp.

Steppan S, Adkins R, Anderson J (2004) Phylogeny and divergence-date estimates of rapid radiations in muroid rodents based on multiple nuclear genes. Syst Biol 53(4):533-53

Stojčević D, Marinculić A, Mihaljević Ž (2002) Prevalence of Capillaria hepatica in Norway rats (Rattus norvegicus) in Croatia. Vet arhiv 72(3):141-149

Storer TJ (1962) Pacific island rat ecology. Bernice P. Bishop Museum, Honululu Bull. 225, 274pp. In: Farhang-Azad A, Schlitter DA (1978) Capillaria hepatica in small mammals collected from Shoa Province, Ethiopia. J Wildl Dis. 14: 358-361 
Stuart P, Golden O, Zintl A, de Waal T, Mulcahy G, McCarthy E, Lawton C (2013) A coprological survey of parasites of wild carnivores in Ireland. Parasitol Res 112(10):3587-93. doi:10.1007/s00436-0133544-7

Syed-Arnez ASK, Mohd Zain SN (2006) A study on wild rats and their endoparasite fauna from the Endau Rompin National Park, Johor. Malaysian Journal of Science 25(2):19-39

Tenora F (1963) Review of parasitic worms in rodents of the genus Apodemus in Czechoslovakia. Zool. Listy. Brno. 12: 331-336. In: Asakawa M, Tenora F (1996) A checklist of nematode parasites of the genus Apodemus (Murinae: Rodentia) throughout the world excluding Japan. J. Rakuno Gakuen Univ 20 (2): 181-213

Tenora F, Zavadil R (1967) A contribution to the evaluation of capillariid nematodes found in rodents in Czechoslovakia. Acta Universitatis Agriculturae 15: 357-368. In: Schmidt S (2001) Untersuchungen zum Vorkommen von Capillaria hepatica und Metazestoden der Cyclophyllida bei Wildmäusen in Deutschland. $\mathrm{PhD}$ Thesis, Universität., Veterinärmedizinische Fakultät, Leipzig: $145 \mathrm{pp}$.

Tenora F, Andreassen O, Hindsbo O, Loda J (1991) Helminths of small rodents in Denmark. Helminthologia 28:151-154

Tinnin DS, Ganzorig S, Gardner SL (2011) Helminths of small mammals (Erinaceomorpha, Soricomorpha, Chiroptera, Rodentia, and Lagomorpha) of Mongolia. Faculty Publications from the Harold W. Manter Laboratory of Parasitology. pp. 669

Tokobaev MM (1960) Gel'mintofauna gryzunov Kirgisii. Trudy Gel'mintologifeskoj Laboratorii 10: 235-247. In: Schmidt S (2001) Untersuchungen zum Vorkommen von Capillaria hepatica und Metazestoden der Cyclophyllida bei Wildmäusen in Deutschland. PhD Thesis, Universität., Veterinärmedizinische Fakultät, Leipzig:145pp.

Tokobaev MM (1976) Gelminty dikich mlekopitajuscich Srednej. Asii. Izd. "ILIN", Frunze: pp. 179. In: Asakawa M, Tenora F (1996) A checklist of nematode parasites of the genus Apodemus (Murinae: Rodentia) throughout the world excluding Japan. J. Rakuno Gakuen Univ 20 (2): 181-213

Torres P, Gonzalez H (1972) Capilariasis hepatica en Valdivia, primera comprobacion en Chile. Arch Med Veterinaria Vol 4(2):30-32

Traversa D, Di Cesare A, Lia RP, Castagna G, Meloni S, Heine J, Strube K, Milillo P, Otranto D, Meckes O, Schaper R (2011) New insights into morphological and biological features of Capillaria aerophila (Trichocephalida, Trichuridae). Parasitol Res 109(Suppl 1):S97104. doi:10.1007/s00436-011-2406-4

Tubangui MA (1931) Worm parasites of the brown rat (Mus norvegicus) in the Philippine Islands, with special reference to those forms that may be transmitted to human beings. The Philipp J Sci 46:637-687

Tung KC, Hsiao FC, Yang CH, Chou CC, Lee WM, Wang KS, Lai CH (2009) Surveillance of endoparasitic infections and the first report of Physaloptera sp. and Sarcocystis spp. in farm rodents and shrews in central Taiwan. J Vet Med Sci 71(1):43-7

Tung KC, Hsiao FC, Wang KS, Yang CH, Lai CH (2013) Study of the endoparasitic fauna of commensal rats and shrews caught in traditional wet markets in Taichung City, Taiwan.J. Microbiol Immunol Infect 46(2):85-8. doi:10.1016/j.jmii.2012.01.012

Vanni V (1938) Sul potere cirrogeno delle uova di Capillaria hepatica. Annali d'Igiene 48: 529-531. In: Schmidt S (2001) Untersuchungen zum Vorkommen von Capillaria hepatica und Metazestoden der Cyclophyllida bei Wildmäusen in Deutschland. PhD Thesis, Universität., Veterinärmedizinische Fakultät, Leipzig:145pp.

Vanni V (1947) Sobre algunas metaplasias producidas por helmintos. Archivos de la Sociedad de Biologia de Montevideo 14: 11-13. In: Schmidt S (2001) Untersuchungen zum Vorkommen von Capillaria hepatica und Metazestoden der Cyclophyllida bei Wildmäusen in Deutschland. PhD Thesis, Universität., Veterinärmedizinische Fakultät, Leipzig:145pp.
Vogelsang EG, Espin J (1949) Dos nuevos huespedes para Capillaria hepatica (BANCROFT, 1893) TRAVASSOS 1915; nutria (Myopotamus coypus) y el raton mochilero (Akodon venezuelensis). Revista de medicina veterinaria y parasitologia 8: 73-78. In: Schmidt S (2001) Untersuchungen zum Vorkommen von Capillaria hepatica und Metazestoden der Cyclophyllida bei Wildmäusen in Deutschland. PhD Thesis, Universität., Veterinärmedizinische Fakultät, Leipzig:145pp.

Wan X, Liu W, Zhao T, Jing Y, Guo P, Shi Y, Wang G (2007a) Relationship between the infective characters of Capillaria hepatica and the body mass of the Brandt's vole (Lasiopodomys brandtii). Acta Theriol Sin 27(2):165-169

Wan XR, Jing Y, Wang GH, Sa RH, Lou JP, Guan QG, Yu C, Du SY (2007b) Relationship between Phodopus campbelli age and population density and Capillaria hepatica infective rate. Chinese J Ecology 26(4):515-518

Wang Z, Lin X, Wang Y, Cui J (2013) The emerging but neglected hepatic capillariasis in China. Asian Pac J Trop Biomed 3(2):1467. doi:10.1016/S2221-1691(13)60039-8

Wantland WW, Kemple HM, Beers GR, Dye KE (1956) Cysticercus fasciolaris and Capillaria hepatica in Rattus norvegicus. Trans Ill Acad Sci. 49, 177-181. In: Schmidt S (2001) Untersuchungen zum Vorkommen von Capillaria hepatica und Metazestoden der Cyclophyllida bei Wildmäusen in Deutschland. PhD Thesis, Universität., Veterinärmedizinische Fakultät, Leipzig:145pp.

Warwick T (1937) The occurrence of disease among muskrats (Ondatra zibethica) in Great Britain during 1934. J Anim Ecol. 6: 112-114. In: Schmidt S (2001) Untersuchungen zum Vorkommen von Capillaria hepatica und Metazestoden der Cyclophyllida bei Wildmäusen in Deutschland. PhD Thesis, Universität., Veterinärmedizinische Fakultät, Leipzig:145pp.

Webster JP, Macdonald DW (1995) Parasites of wild brown rats (Rattus norvegicus) on UK farms. Parasitology 111:247-255

Wilamowski A, Moran S, Greenburg Z (2002) Commensal rodents and their parasites in Israel. In Proceedings of the 4th international conference on urban pests. Charleston, South Carolina, USA. 103-112.

Wilson K, Eady P, del Nevo AJ (1998) Origin of an insular population of the wood mouse based on parasitological evidence. J Wildl Dis 34(1):150-4

Winfield GF (1933) Quantitative experimental studies on the rat nematode, Heterakis spumosa Schneider. Amer. J. Hyg. 17: 168-228. In: Lubinsky G (1956) On the probable presence of parasitic liver cirrhoses in Canada. Can J Comp Med Vet Sci. 20: 457-465

Wiroreno W (1978) Nematode parasites of rats in West Java, Indonesia. Southeast Asian J Trop Med Public Health 9: 520-525. In: Schmidt S (2001) Untersuchungen zum Vorkommen von Capillaria hepatica und Metazestoden der Cyclophyllida bei Wildmäusen in Deutschland. PhD Thesis, Universität., Veterinärmedizinische Fakultät, Leipzig:145pp.

Wright KA (1961) Observations on the life cycle of Capillaria hepatica (BANCROFT, 1893) with a description of the adult. Can J Zool. 38: 167-182. In: Schmidt S (2001) Untersuchungen zum Vorkommen von Capillaria hepatica und Metazestoden der Cyclophyllida bei Wildmäusen in Deutschland. PhD Thesis, Universität., Veterinärmedizinische Fakultät, Leipzig:145pp.

Wu X (1930) A study of the common rat and its parasites. Lignan Sc. Jour. 9: 51-64. In: Seo BS, Rim HJ, Lee CW, Yoon JS (1964) Studies on the parasitic helminths of Korea: II. Parasites of the rat, Rattus norvegicus Erxl. In Seoul, with the description of Capillaria hepatica (Bancroft, 1893) Travassos, (1915). Kisaengchunghak Chapchi. 2(1):55-62

Xiong MT, Rong YG, Xing W, Xiong MT, Yang GR, Wu X (1999) Investigation of small mammals with Capillaria hepatica in Weishan County. Endemic Diseases Bulletin 14(3):58-60

Xue YS, Wu CH, Huang MS, Li RH (1998) Investigation on rats infected with Capillaria hepatica in Fuqing. Haixia Yufang Yixue Zazhi 4: 
31-32. In: Li CD, Yang HL, Wang Y (2010) Capillaria hepatica in China. World J Gastroenterol. 16(6):698-702

Yagisawa M (1978) Studies on zoonotic helminths from mammals in Northern Honshu, Japan. Hirosaki Medical Journal 2(30): 239-284

Yang ZH, Lu KH (2000) Survey of Angiostrongylus cantonensis and Capillaria hepatica in field rodents in Taiwan. Taiwan J Vet Med Anim Husb 70:51-57

Yi JY, Kim YH, Kim HC, Hahn TW, Jeong H, Choi CU, Woo GH, Kim YB, Han JH, Yoon BI (2010) Prevalence of hepatic parasites in Korean wild rats (Rattus norvegicus) and their association with pulmonary arteriolar medial hypertrophy. Vet Pathol 47(2):292-7. doi:10.1177/0300985809359306

Yuan GL, Li XY, Chen WJ (2000) Investigation on Rattus losea infected with Capillaria hepatica in Ningde. Zhongguo Meijie Shengwuxue Ji Kongzhi Zazhi 11: 301-302. In: Li CD, Yang HL, Wang Y
(2010) Capillaria hepatica in China. World J Gastroenterol. 16(6): 698-702

Zhang LY, Huang JY, Yang FZ (2003) Investigate on rats infected with Capillaria hepatica in Jiangle. Zhongguo Jishengchoubing Fangzhi Zazhi 16: 19-20. In: Li CD, Yang HL, Wang Y (2010) Capillaria hepatica in China. World J Gastroenterol. 16(6):698702

Zhou XM, Zhang GF, Li C, Li FH, Yin ZH, Yang JL, Su P (1998) Investigation on rats infected with Capillaria hepatica in Kunming. Zhongguo Renshou Gonghuanbing Zazhi 14: 33. In: Li CD, Yang HL, Wang Y (2010) Capillaria hepatica in China. World J Gastroenterol. 16(6):698-702

Zhou ZL, Wu HY, Mao XP, Fang ZM (1991) Investigate the infection rate of Capillaria hepatica on rats. Zhongguo Bingyuan Shengwuxue Zazhi 4: 225. In: Li CD, Yang HL, Wang Y (2010) Capillaria hepatica in China. World J Gastroenterol. 16(6):698-702 